\title{
Türkçe öğretmeni adaylarının Türkçedeki alıntı sözcükler hakkındaki görüşlerinin incelenmesi ${ }^{1}$
}

İsmail ÇOBAN²

\section{Cengiz ALYILMAZ3}

\begin{abstract}
APA: Çoban, İ., Alyılmaz, C. (2019). Türkçe öğretmeni adaylarının Türkçedeki alıntı sözcükler hakkındaki görüsslerinin incelenmesi. RumeliDE Dil ve Edebiyat Araştırmaları Dergisi, (16), 40-68. DOI: $10.29000 /$ rumelide. 616884
\end{abstract}

$\ddot{\mathbf{O z}}$

Dillerin doğallıkları içinde başvurdukları yollardan birisi de diğer dillerden ödünçlemeler yapmaktır. Bu ödünçlemeler ses düzeyinden cümle düzeyine kadar olabilmektedir. Bu ödünçlemeler içinde en fazla dikkat çekeni de sözcük düzeyindeki ödünçlemeler, alıntı sözcüklerdir. Dünya dilleri gibi Türkçe de yazılı kaynaklardan takip edebildiğimiz kadarıyla Eski Türkçe Dönemi de dâhil olmak üzere tarihî ve çağdaş tüm dönemlerinde alıntı sözcükleri içinde barındırmıştır. Alıntı sözcüklerin dildeki sayılarının arttı̆̆ı her dönemde bu sözcüklerin Türkçeye geçiş hızlarını kesmek, Türkçecilik bilinci ile hareket eden herkesin (devlet adamı, sanatçı, düşünür vd.nin) vazifelerinden birisi olmuştur. Günümüzde dünya dillerinin içerisinde barındırdı̆̆ı alıntı sözcük oranı ile Türkçedeki alıntı sözcük oranının benzerlik gösterdiği bilinmektedir. Türkçenin öğretimi hususunda büyük rol üstlenecek Türkçe öğretmeni adaylarının bu sözcükler hakkındaki görüşlerinin ve bunlara yaklaşımlarının belirlenmesi amacıyla gerçekleştirilen bu çalışmada nitel araştırma yöntemlerinden tarama modeli kullanılmıştır. Araştırmanın çalışma grubunu, 2016-2017 eğitim öğretim yılında Atatürk Üniversitesi Türkçe Eğitimi Ana Bilim Dalında öğrenim gören tüm sınıf düzeylerinden ikişer kişi olmak üzere toplamda 8 Türkçe öğretmeni adayı oluşturmaktadır. Türkçe öğretmeni adaylarının alıntı sözcüklerin dildeki kullanımı ve bu sözcüklere ilişkin görüşlerinin alınması amacıyla geliştirilen görüşme formu uygulanmıştır. Ses kayıt cihazıyla kaydedilen görüşme kayıtları yazıya geçirilmiş; içerik analizi tekniği ile çözümlenerek ulaşılan veriler kendi arasında sınıflandırmaya tabi tutularak kodlar oluşturulmuştur. Dildeki çeşitliliği artırıp dilin devamlılığının sağlanması, canlılı̆̆ının korunması gibi özellikler taşıyan alıntı sözcükler hakkında Türkçe öğretmeni adaylarının bu sözcükleri belirlerken bazı kurallardan hareket ettikleri, alıntı sözcüklerin Türkçede bulunmasını normal karşıladıkları, bunu dilin olması gereken bir süreci olarak gördükleri tespit edilmiştir. Türkçe öğretmeni adaylarının aynı zamanda bu sözcüklerin fazla kullanımını hoş karşılamadıkları, gerek özenti gerek teknoloji gerekse kitle iletişim araçlarının yabancı sözcüklerin sıklıkla kullanılmasına sebep olmasını hoş karşılamadıkları ve bunun Türkçede yozlaşmaya sebep olacağını öngördükleri, alıntı sözcük almak yerine ilk önce Türkçenin tarihî ve çağdaş kaynaklarına başvurmak gerektiği ve Türk Dil Kurumunun yeni sözcükler için karşılık bulma çalışmalarını olumlu gördükleri yönünde temel görüşlere sahip oldukları sonuçlarına ulaşılmıştır.

\footnotetext{
1 Bu makale, “Türkçe Öğretmeni Adaylarının Türkçedeki Alntı Sözcükleri Kullanma Düzeylerinin İncelenmesi (2018)" adlı doktora tezinden hareketle (bazı güncellemeler ve eklemeler de yapılarak) oluşturulmuștur.

2 Dr., Artvin Çoruh Üniversitesi, Eğitim Fakültesi, Türkçe Eğitimi Bölümü, smlcoban@gmail.com (Artvin / Türkiye), ORCID ID: oooo-0003-3952-9350 [Makale kayit tarihi: 03.07.2019-kabul tarihi:19.09.2019; DOI: 10.29000/rumelide.616884]

3 Prof. Dr., Uludağ Üniversitesi Fen Edebiyat Fakültesi Türk Dili ve Edebiyatı Bölümü, ORCID ID: 0ooo-0002-3634-9015 (Bursa/ Türkiye), calyilmaz@gmail.com.
} 
Anahtar kelimeler: Görüşme, alıntı sözcük, özenti, kitle iletişim araçları, Türkçe öğretmeni adayları.

\title{
Investigation of prospective Turkish teachers' views on loan words in Turkish
}

\begin{abstract}
One of the methods that languages apply in their naturalness is to borrow from other languages. These borrowings can range from phonology to syntax. The most noteworthy of these borrowings are morphological borrowings and loan words. Like the languages of the world, Turkish has contained loan words in all historical and contemporary periods including the Old Turkish Period as far as we can follow from written sources. In every period, when the number of loan words in the language increases, interrupting the speed of these words into Turkish has been one of the duties of everyone who acts with the Turkish consciousness (statesman, artist, thinker etc.) Today it is known that the rate of loan words in world languages is similar to the one in Turkish. In this study survey method, one of the qualitative research methods, has been used to determine the views and approaches of the prospective Turkish teachers who will play a major role in teaching Turkish. The study group of the research consists of 8 prospective Turkish teachers, two students of all grades ,studying at Ataturk University Turkish language teaching department in 2016-2017 academic year. The interview form, developed to understand the opinions of prospective Turkish teachers about the loan words and the use of loan words in the language, has been applied. The recordings of the interviews recorded with the voice recorder were transcribed and the content analyzing technique was used to analyze the data and codes were formed. It was found that prospective Turkish teachers acted according to some rules while determining loan words which have features such as increasing the diversity in the language and ensuring the continuity of the language and preserving the viability of the language, that they accept the existence of loan words in Turkish as a process that is the need of the language. On the other hand they do not welcome the excessive use of loan words, because of wannabe, technology and mass media tools' using loan words frequently. They predicts that this will lead to corruption in Turkish and instead of using loan words one must first refer to the historical and contemporary sources of Turkish and it has been concluded that prospective Turkish teachers welcome the Turkish language institution's finding correspondences for the new words.
\end{abstract}

Keywords: Interview, loan word, wannabe, mass media tools, prospective Turkish teachers.

\section{Ø. Giriș}

Dillerin kavramları işaretlerken başvurdukları yollardan biri olan ödünçleme, birbirleriyle dinî, ticari, coğrafi $v b$. alanlarda etkileşim hâlinde olan milletlerin yeni bir kavramla karşılaştıklarında her zaman başvurdukları öncelikli yollardan birisidir. Ödünçleme İmer, Kocaman ve Özsoy’a (2011, s. 199) göre "Bir başka dilden öge alma; çeşitli siyasal, toplumsal, kültürel, ekonomik $v b$. nedenlere dayanan ödünçleme, sesbirim, sözcük, biçimbirim ve söz dizimi düzeylerinde olmak üzere dilin her düzeyinde görülebilir” şeklinde tanımlanmaktadır. Bu ödünçlemelerin en ilgi çekeni bilim dünyası tarafından araştırılmaya, incelenmeye layık görüleni sözcük düzeyindeki alıntılar olmuştur.

Alıntı ve alıntı sözcük kavram işaretleri ise ödünçlemeden daha özel ele alındığı zaman şu anlamlarda karşımıza çıkmaktadır: Alıntı (loan), "Bir dile çeşitli etkiler, özellikle kültür etkileri dolayısıyla başka bir dilden ses, söz, ek veya kural” (Karaağaç, 2013, s. 99); alıntı sözcük (loan word) ise "Farklı kurulumlarla, 
iyi oluşturulmuş şartlarla bir dilden başka bir dile giren ve dildeki düzenlemelerle yeni kısıtlamalara tabi tutulan sözcükler" (Yip, 1993).

Geniş bir kullanım alanı gösteren Türkçe, karşılaştığı kültür sayısı, etkileşim içine girdiği dil fazlalığı sebebiyle bu dillerden sözcük düzeyinde alıntı yapmaktan geri durmamış, bu dillere de sözcükler vermiştir. Her dönemin kendi ilgi alanına göre farklılık gösteren alıntı sözcüklerin son yıllarda Türkçeye girme sebeplerinin başında bilinçsizce süregelen Batı hayranlığı ile aynı zamanda bilinçsiz bir biçimde yeni sözcüklerin alınması yer almaktadır. Son yıllardaki diğer önemli alıntı sözcük alma nedenlerini, özenti, teknoloji, kitle iletişim araçları, çeviriler, yabancı dil eğitimi ile yabancı dilde eğitim ve ticari kaygılar oluşturmaktadır.

\section{Özenti}

Televizyon ve sinemanın etkisiyle Türkçe sözcüklerle ifade edilen kavramlar ve yeni karşlaşılan kavramlar için yabancı dillerdeki karşlıkları tercih edilmeye başlanmıştır. Yabancı bir kelimenin bulunduğu / geçtiği eşyalar giysi, kap kacak, süs eşyaları $v d$. daha fazla ilgi çektiğinden tercih edilir olunca bir zaman sonra bunlar üzerindeki sözcüklerin anlamlarına dahi dikkat edilmeden bunlar üretilip piyasaya sürülmüştür. "Özellikle 200o'li yıllardan sonraki defter kapaklarını inanılmaz bir şekilde İngilizce kelimeler istila etmiştir. 1980 ve 1990 'lı yıllara ait defter kapaklarının merkezinde ve önemli yerlerinde görülen Türkçe / alıntı kelimeler, sonraki yıllarda bulundukları yerleri birer birer Türkçede hiç kullanılmayan İngilizce kelimelere bırakmak zorunda kalmışlardır” (Kara, 2007, s. 392).

\section{Teknoloji}

Teknolojik bir ürün kendisi ile birlikte ürünü meydana getiren parçalar ve ürünün oluşturulmasındaki aşamalarla ilgili sözcükleri de beraberinde getirmektedir. "Her gelen ürün beraberinde yüzlerce kelimeyi ve kelime grubunu da dilimize taşımaktadır. Bu durum bugün tahammül edilemez bir boyuta ulaşmıştır" (Alyılmaz, 1997, s. 36).

\section{Kitle iletişim araçları}

Kitle iletişim araçlarında hem yayın organlarının isimlerinde hem de programların isimlerinde sıklıkla yabancı sözcüklere, içeriğinde de yabancı sözcük kullanmanın kâr sağlayacağına inanılarak yapılan programlara sıklıkla rastlanmaktadır. "Yabancı dillere ait sözcüklerin Türkçede kullanılması âdeta bir moda hâline gelmiş ve bu moda hızla yayılmaktadır. Özel televizyon kanalları ve radyo isimlerinin hemen hemen hepsi yabancıdır: Star, Flash, Show, Cine 5, Elmax, Fox, Skytürk, Cnntürk, Powertürk, Best, Capitol, City, Joy, Energy, Kiss, Super, Power, Slow, Rock, First vb.” (Güllüdağ, 2012, s. 51).

\section{Çeviriler}

Son zamanlarda televizyon, sinema ve kitap çevirilerinde özensiz bir tutum söz konusudur. Çevirmenlerin kendilerinin iyi düzeyde bildikleri dillerden yaptıkları çevirilerde bazı kelimeler için bilinçli veya bilinçsizce orijinalindeki kelimeyi kullanmaları cümledeki anlamdan hareketle o sözcüğü izleyenlerin / okuyanların anlamlandırmalarına ve kullanmalarına sebep olmaktadır. "Günümüzde özellikle basın-yayının etkisiyle, günlük konuşmalarda sıklıkla kullanılan ifadelerin çoğu İngilizceden aktarma ve Türkçeye uyarlanmış çevirilerdir. Bunların büyük bir kısmı da yabancı film ve dizilerin Türkçeye aktarılması sırasında Türkçeyi iyi bilmeyen kişilerce veya İngilizcenin mantığına uygun 
biçimde metin çevirenlerce ortaya çıkarılan 'dublaj Türkçesi’nden kaynaklanmaktadır” (Karakılıç Akı, 2007, s. 214).

\section{Yabancı dil eğitimi ve yabancı dilde eğitim}

Okul öncesinden başlamak üzere eğitim öğretimde yabancı dil eğitimi verilmesi ve yabancı dilde eğitim yapılmaya başlanması da Türkçeye giren alıntı sözcük sayısındaki artışın sebeplerinden biridir. Ana dili bilincine varılmadan gerçekleştirilen bu eğitimler Türkçe üzerinde olumsuz bir etki bırakmaktadır. "Yabancı dil öğrenmenin gereğini ve önemini hiç kimse inkâr edemez; ama bunun için yabancı dille öğrenim görmeye hacet yoktur. Yabancı dille öğrenmek, bilimde ve teknikte yabancıların mantığı ile düşünmek ve konuşmak demektir” (Ünver, 1991, s. 78).

\section{Ticari kaygilar}

Ticari kâr elde etmenin yollarından biri de farklı olmak, "İthal edilen ürün kalitelidir", "Yabancı bir ürün denenmelidir", "Yabanctysa iyidir" şeklindeki düşünceler doğrultusunda hareket etmektir. Markalar ya yabancı dilde bir isim kullanmakta ya Türkçe bazı isimlerin kısaltmalarını birleştirerek yabancı izlenimi vermekte ya da yöresel ağızlardan bilinmedik yabancıymış gibi görünen sözcükleri tercih etmektedirler. "Özentinin yanında ekonomik kaygılar bu tür adlandırmalarda oldukça etkili olmaktadır. Markalarını yabancı pazarlara açmak ve uluslararası veya ulusal önyargılardan korkarak ürünlerin Türkiye çıkışlı olduğunu gizlemek amacı da isimlerde oynanmaya sebep olabilmektedir" (Demirci, 2013, s. 352).

\section{Araştırmanın amacı}

Türkçe öğretmeni adaylarının Türkçedeki alıntı sözcükler hakkındaki görüşlerini ortaya koymak amacıyla gerçekleştirilen bu çalışmada "Türkçe öğretmeni adaylarının Türkçedeki alıntı sözcükler hakkındaki görüşleri nasıldır?” sorusuna cevap aranmıştır. Bu doğrultuda ele alınan çalışmaya ait alt problemleri ise şu sorular oluşturmaktadır:

Türkçe öğretmeni adaylarının;

a. Alıntı sözcüklerde dikkatlerini çekenler nelerdir?

b. Alıntı sözcüklerin hangi dilden geldiğini belirleme yolları nelerdir?

c. Alıntı sözcüklerin yerine Türkçe kökenli eş anlamlılarını kullanma hakkında görüşleri nelerdir?

d. Alıntı sözcüklerin yazımlarının karıştırılmaması için neler yapılabileceği konusunda önerileri nelerdir?

e. Alıntı sözcükler söylenirken yaşanan zorluklar için neler yapılabileceği hususundaki fikirleri nelerdir?

f. Türkçesi varken yeni bir alıntı sözcügün Türkçede yer alması hakkındaki düşünceleri nelerdir?

g. Alıntı sözcüklerin Türkçeye girmesinde etkili olan yollar hakkındaki görüşleri nelerdir?

h. Yabancı dilde yayın yapan yayın organlarının Türkçeye yeni alıntı sözcükler girmesindeki etkisi konusunda fikirleri nelerdir?

i. Bir sözcük için alıntılama yapılacaksa bunun hangi dillerden olması gerektiği hususundaki görüşleri nelerdir?

j. Yabancı dilde eğitimin Türkçeye yeni sözcüklerin girmesi üzerindeki etkisi hakkındaki düşünceleri nelerdir?

k. Çevirilerin Türkçeye yeni sözcüklerin girmesi üzerindeki etkisi hakkındaki fikirleri nelerdir? 


\section{Yöntem}

Bu bölümde araştırma deseni, çalışma grubu, verilerin toplanması ve verilerin analizi hakkında bilgiler sunulmuştur.

\subsection{Araşturma deseni}

Atatürk Üniversitesinde öğrenim gören Türkçe öğretmeni adaylarının Türkçedeki alıntı sözcükler hakkındaki görüşlerini ortaya koymak amacıyla tarama modelinde yapılan bu çalışmada nitel araştırma deseni kullanılmıştır. "Nitel araştırma, gözlem, görüşme ve doküman analizi gibi nitel veri toplama yöntemlerinin kullanıldığı, olguların ve olayların doğal ortamda gerçekçi ve bütüncül bir biçimde ortaya konmasına yönelik nitel bir sürecin izlendiği araştırma olarak tanımlanabilir" (Yıldırım ve Şimşek, 2008, s. 39; Büyüköztürk vd., 2009). Nitel araştırmalarda veriler teker teker araştırmacı tarafından okunup kodlanır ve kategorize edilir.

\section{2. Çalışma grubu}

Araştırma, 2016-2017 eğitim öğretim yılında Atatürk Üniversitesi Türkçe Eğitimi Ana Bilim Dalında öğrenim gören bütün sınıf düzeylerinden ikişer öğretmen adayı olmak üzere toplamda 8 Türkçe öğretmeni adayyyla gerçekleştirilmiştir.

Çalışmada amaçlı örnekleme yöntemlerinden kolay ulaşlabilir durum örneklemesi kullanılmıştır. Çalışmada kolay ulaşılabilir durum örneklemesi kullanılmasının nedeni seçilen öğrencilerin Atatürk Üniversitesinde öğrenim görmesi dolayısıyla kolay ulaşılabilir bir konumda olmaları ve çalışmaya katılmak için gönüllü olmalarıdır. "Bu örnekleme türü, araştırma yapılacak birey ya da grupların araştırma sürecine dâhil edilmesinin daha kolay ya da bunlara daha kolay ulaşılabilir olmasıyla ilişkilidir" (Ekiz, 2009, s. 106).

Alıntı sözcüklere ilişkin görüşlerin, farkındalıkların ortaya çıkarılması amacıyla gerçekleştirilen görüşmelere katılan Türkçe öğretmeni adaylarına dair kişisel bilgiler şu şekildedir:

Tablo 1: Görüşmeye katılan Türkçe öğretmeni adaylarının kişisel bilgileri

\begin{tabular}{|c|c|c|c|c|c|c|}
\hline & Cinsiyet & Yaş & Sinif & Agno & Bilinen Yabancı Dil ve Düzeyi & Görüşme Süreleri \\
\hline$\ddot{\mathrm{O}}_{1}$ & $\mathrm{Kiz}$ & 24 & 1 & 3,78 & - & $31: 15 d k$. \\
\hline$\ddot{\mathrm{O}}_{2}$ & Erkek & 22 & 1 & 2,40 & İngilizce (A2) & $29: 59 d k$. \\
\hline$\ddot{\mathrm{O}}_{3}$ & Erkek & 21 & 2 & 1,95 & İngilizce (A2) & $25: 34 d k$. \\
\hline$\ddot{\mathrm{O}}_{4}$ & $\mathrm{Kuz}$ & 20 & 2 & 2,30 & - & 30:03 $d k$. \\
\hline$\ddot{\mathrm{O}}_{5}$ & $\mathrm{Kiz}$ & 21 & 3 & 3,37 & İngilizce (B1) & 26:07 dk. \\
\hline$\ddot{\mathrm{O}}_{6}$ & $\mathrm{Kuz}$ & 21 & 3 & 3,35 & İngilizce (A2) & $30: 20 d k$. \\
\hline$\ddot{\mathrm{O}}_{7}$ & Erkek & 22 & 4 & 2,65 & İngilizce (A1) & $28: 32 d k$ \\
\hline$\ddot{\mathrm{O}}_{8}$ & $\mathrm{Kiz}$ & 22 & 4 & 3,30 & İngilizce (B1) & $26: 17 d k$. \\
\hline
\end{tabular}

Tablo 1 görüşmeye katılan Türkçe öğretmeni adaylarının kişisel bilgilerini göstermektedir. Görüşmeye katılan Türkçe öğretmeni adaylarından 5 ’ kız, 3 ’ü ise erkektir. Bu öğretmen adaylarının yaşları ise 2024 yaş aralığındadır. Sınıf düzeyi olarak ise her sınıf düzeyinden 2 öğretmen adayı ile görüşülmüsstür. Ağırlıklı Genel Not Ortalaması (Agno) seviyelerinin ise 1 öğretmen adayının 1,00 - 2,00; 3 öğretmen 
adayının 2,00 - 3,00 ve 4 öğretmen adayının da 3,00 - 4,00 aralığında olduğu görülmektedir. Görüşmeye katılanların 2'si yabancı dil bilmemektedir ve geriye kalanlar ise İngilizce bilmektedir. Türkçe öğretmeni adaylarının bildikleri diller ve dil düzeyleri için kendi beyanları esas alınmıştır. Yapılan görüşmelerden en kısası 25:34 $d k$. en uzunu 31:15 $d k$. sürmüştür.

\subsection{Veri toplama aracı}

Nitel araştırmaların bulgularını görüşme, gözlem ve dokümanlarla toplanan veriler oluşturmaktadır (Merriam, 2013). Bu araştırmada Türkçe öğretmeni adaylarının alıntı sözcüklerin dildeki kullanımı ve bu sözcüklere ilişkin görüşlerinin belirlenmesi amacıyla geliştirilen görüşme formu uygulanmıştır.

"Nitel yöntemlerden en sık kullanılanı görüşmedir. Görüşme insan bakış açılarını, deneyimlerini, duygularını ve algılarını ortaya koymada kullanılan oldukça güçlü bir yöntemdir" (Bogdan ve Biklen, 1992'den akt. Yıldırım ve Şimşek, 2006, s. 40).

Görüşme formu oluşturulurken temel 23 görüşme sorusuna ve bunların alt sorularına yer verilmiştir. Ardından Türkçe Eğitimi Ana Bilim Dalında görev yapan 1 Profesör, 1 Doçent, 2 Dr. ve 2 Araştırma Görevlisinden uzman görüşü alınmıştır. Uzman görüşleri doğrultusunda "Bildiğiniz yabancı dillerdeki kelimeleri Türkçeye taşıyor musunuz?”, "Yeni kavramlar için Türkçe karşllık bulunmasında Türk Dil Kurumunun çalışmaları hakkındaki görüşleriniz nelerdir?”, “Yeni bir kavram için Türkçe sözcük oluşturmak için nasıl çalışmalar yapılabilir?”, “Gazete ve televizyonlarda kullanılan Türkçede olmayan yabancı sözcükler hakkındaki düşünceleriniz nelerdir?” soruları formdan çıarılmıştır.

Ardından Atatürk Üniversitesi Türkçe Eğitimi Ana Bilim Dalında öğrenim gören 2 Türkçe öğretmeni adayıyla pilot uygulama olarak görüşme gerçekleştirilmiştir. Pilot uygulamanın gerçekleştirildiği Türkçe öğretmeni adaylarına ilişkin kişisel bilgiler şu şekildedir:

Tablo 2: Pilot uygulamanın gerçekleştirildiği Türkçe öğretmeni adaylarına ilişkin kişisel bilgiler

\begin{tabular}{llllll}
\hline Cinsiyet & Yaş & Sınıf & Agno & $\begin{array}{l}\text { Bildiği } \\
\text { Yabancı Dil }\end{array}$ & $\begin{array}{l}\text { Görüsşme } \\
\text { Süresi }\end{array}$ \\
\hline Kiz & 20 & 3 & $3,00-4,00$ & İngilizce & $44: 25 d k$ \\
Erkek & 21 & 4 & $2,00-3,00$ & İngilizce & $41: 12 d k$ \\
\hline
\end{tabular}

Yapılan görüşmelerin ardından cevapları diğer soruların da içinde geçtiği anlaşılan "Sosyal medyada kullanılan Türkçenin ne kadar doğru olduğunu düşünüyorsunuz? Sosyal medyanın diğer dillerden alıntı yapmada nasıl bir rolü vardır?”, “Türkçedeki alıntı sözcüklerin yerine Türkçe karşılıklar oluşturularak bu sözcükler Türkçeden çıkarılmalı mıdır?”, “Özel isimlerde yabancı sözcüklerin kullanılmasının alıntılama üzerindeki etkileri hakkındaki düşünceleriniz nelerdir?” sorularının formdan çıkarılmasına karar verilmiş ve görüşme formuna son şekli verilmiştir.

\subsection{Verilerin analizi}

Ses kayıt cihazıyla kaydedilen görüşme kayıtları yazıya geçirilerek elektronik ortama aktarılmıştır. İçerik analizi tekniği ile çözümlenerek ulaşılan veriler kendi arasında sınıflandırmaya tabi tutularak kodlar oluşturulmuştur. Türkçe öğretmeni adayları için $\ddot{O}_{1}, \ddot{O}_{2}, \ddot{O}_{3}$ şeklinde kısaltmalar kullanılmış ve öğretmen adaylarının görüsslerine de yer verilmiştir. Çalışmanın güvenirliğini sağlamak için iki ayrı puanlayıcı verileri incelemiştir. 


\section{Bulgular}

Bu bölüm, Türkçe öğretmeni adaylarının alıntı sözcükler hakkındaki görüşlerinin çeşitli yönlerden belirlenmeye çalışıldığı bulgulardan oluşmaktadır:

\subsection{Türkçe öğretmeni adaylarının alıntı sözcüklerde dikkatlerini çekenler hakkındaki görüşlerine dair bulgular}

Alıntı sözcüklerin Türkçe öğretmeni adayları tarafından fark edilebilme ve bu fark etmede öne çıkan özelliklerin neler olduğunu belirlemek amacıyla yöneltilen sorular sonucunda elde edilen bulgulara bu bölümde yer verilmiştir.

Tablo 3: Türkçe öğretmeni adaylarının alıntı sözcüklerde dikkatlerini çekenler hakkındaki görüşleri

\begin{tabular}{ll}
\hline Alıntı sözcükleri fark edebilme ve bunların özellikleri & $\mathbf{f}$ \\
\hline Fark edebilme $\ddot{\mathrm{O}}_{1}, \ddot{\mathrm{O}}_{2}, \ddot{\mathrm{O}}_{5}, \ddot{\mathrm{O}}_{6}$ & 4 \\
\hline Kısmen fark edebilme $\ddot{\mathrm{O}}_{3}, \ddot{\mathrm{O}}_{4}, \ddot{\mathrm{O}}_{7}, \ddot{\mathrm{O}}_{8}$ & 4 \\
\hline Türkçenin ses özellikleri $\ddot{\mathrm{O}}_{1}, \ddot{\mathrm{O}}_{2}, \ddot{\mathrm{O}}_{3}$ & 3 \\
\hline Alıntı sözcüklerin ses özellikleri $\ddot{\mathrm{O}}_{4}, \ddot{\mathrm{O}}_{5}, \ddot{\mathrm{O}}_{6}, \ddot{\mathrm{O}}_{8}$ & 4 \\
\hline Büyük ünlü uyumunu arama $\ddot{\mathrm{O}}_{2}$ & $\mathbf{1}$ \\
\hline Aynı coğrafyayı paylaşma $\ddot{\mathrm{O}}_{6}$ & $\mathbf{1}$ \\
\hline Yazı dilindeki belirginlik $\ddot{\mathrm{O}}_{7}$ & $\mathbf{1}$ \\
\hline
\end{tabular}

Tablo 3 incelendiğinde Türkçe öğretmeni adaylarının 8’inin de görüş belirttiği görülmektedir. Alıntı sözcükleri 4 Türkçe öğretmeni adayı kolaylıkla fark edebildiğini belirtirken 4’ü ise bunu kısmen gerçekleştirdiklerini özellikle yazı dilinde daha kolay fark ettiklerini, konuşma dilinde geçiş sıklığı yüksek olan sözcükleri ayırt edemediklerini dile getirmişlerdir. Türkçe öğretmeni adaylarından 3 ’ü Türkçenin ses özellikleri, 4’ü de alıntı sözcüklerin ses özellikleri sayesinde alıntı sözcükleri fark edebildiklerini bildirmişlerdir. 1 öğretmen adayı büyük ünlü uyumundan yola çıarak bu sözcükleri belirleyebildiğini, 1 öğretmen adayı alıntı sözcüğün Türkçeye girdiği dili konuşanlarla aynı coğrafyayı paylaştı̆̆ını ve bu sayede o alıntı sözcükleri belirleyebildiğini, 1 öğretmen adayı ise yazı dilinde alıntı sözcüklerin daha belirgin olduğunu ve bu sayede bu sözcükleri fark edebildiğini belirtmiştir. Alıntı sözcüklerin fark edilmesinde Türkçe sözcüklerin ses yapısı ve alıntı sözcüklerin ses yapısının önemli olduğunu ifade etmek mümkündür.

Türkçenin ses özelliklerinden yola çıkarak alıntı sözcükleri belirleyebilenlerden birinin görüşleri şu şekildedir:

Ö$_{2}$ : Şöyle fark edebiliyorum. Bölümüm Türkçe öğretmenliği olduğu için. Kelimenin Türkçe kelime olup olmadığını belirleyebilmek için Türkçe kelime ölçütleri vardır. Bu ölçütlere göre baktığımızda bu büyük ünlü uyumu olabilir ya da iki tane bazı sessiz harfin yan yana gelemeyeceği ve ağır olarak mesela Divan Edebiyatından bir şey okuduğumuz zaman Arapça kökenli olduğunu anlayabiliyoruz ya da yabancı kökenli oluyor anlayabiliyoruz. Alıntı sözcük olduğunu yüzde yüz olmasa da yüzde yetmiş olarak anlayabiliyorum.

Alıntı sözcüklerin ses özelliklerinden hareketle bu sözcükleri fark ettiklerini belirtenlerden birinin görüşü şöyledir: 
Ös: Şöyle söyleyeyim. Örneğin bir metin üzerinde inceleme yaptığımızda bunu fark edebiliyoruz. Ama televizyonlarda ve radyo programlarında duyduğumuz itibarıyla cok fazla fark edemiyoruz biz bunları. Nedenini şöyle düşünüyorum şu şekilde açıklayayım: Biz artık bu kelimeleri içselleştirdik. Hani anlam kayması sayesinde bizim de söylemek istediklerimizi hemen hemen aynı seviyede kullanıyoruz. Konuşma dilinde çok fazla fark edemiyoruz benim kanım bu. Örneğin: Arapçadan aldığımız bir sözcüğü tıpatıp almıyoruz kesinlikle ya ses değişimi oluyor çoğunlukla böyle. Fransızcadan bazı sözcükler ya ses değişimi oluyor ya da anlam kayması yoluyla bir farklılık oluyor. Kelime başındaki iki ünsüzün yan yana gelmemesi de dikkatimi çekiyor.

Yazı dilindeki ayırt ediciliği dikkate alarak alıntı sözcükleri fark edebildiğini 1 Türkçe öğretmeni adayı şu şekilde ifade etmiştir:

$\ddot{O}_{7}:$ Bu sözcükleri daha çok yazı dilinde fark ediyorum zaten konuşma dilinde jest ve mimikler ön planda olduğu için yazı dilinde daha çok fark ediliyor. Bu alıntı sözcükler. Mesela dilimize geçmiş yabancı sözcüklere bakacak olursak ekonomik boyutta bir kelime birden çok anlamı karşılıyorsa o benim dikkatimi çeker ve onu da insanlar kullanmaya daha yatkın olur diye düşünüyorum.

\subsection{Türkçe öğretmeni adaylarının alıntı sözcüklerin hangi dilden geldiğini belirleme yolları hakkındaki görüşlerine dair bulgular}

Alıntı sözcükler söz konusu olduğunda başta gelen özelliklerden birisi de bu sözcüklerin hangi dillerden geldiğinin belirlenebilmesidir. Bu bölümde Türkçe öğretmeni adaylarının alıntı sözcüklerin hangi dillerden geldiğini belirlemeye yönelik görüşleri verilmiştir.

Tablo 4: Türkçe öğretmeni adaylarının alıntı sözcüklerin hangi dilden geldiğini belirleme yolları hakkındaki görüşleri

\begin{tabular}{ll}
\hline Alıntı sözcükleri belirleme yolları & f \\
\hline Popüler kültür $\ddot{\mathrm{O}}_{1}, \ddot{\mathrm{O}}_{4}$ & 2 \\
\hline Televizyon ve sinema $\ddot{\mathrm{O}}_{1}, \ddot{\mathrm{O}}_{5}, \ddot{\mathrm{O}}_{7}$ & 3 \\
\hline Alıntı sözcüklerin fazla olduğu diller $\ddot{\mathrm{O}}_{2}$ & 1 \\
\hline Eğitim dili $\ddot{\mathrm{O}}_{2}$ & 1 \\
\hline Dinî terimler $\ddot{\mathrm{O}}_{3}, \ddot{\mathrm{O}}_{4}, \ddot{\mathrm{O}}_{7}$ & 3 \\
\hline Bilinen yabancı diller $\ddot{\mathrm{O}}_{3}$ & $\mathbf{1}$ \\
\hline Sosyal medya $\ddot{\mathrm{O}}_{3}$ & $\mathbf{1}$ \\
\hline Alınan eğitim $\ddot{\mathrm{O}}_{5}, \ddot{\mathrm{O}}_{6}$ & 2 \\
\hline Sözlük kullanma $\ddot{\mathrm{O}}_{8}$ & $\mathbf{1}$ \\
\hline
\end{tabular}

Tablo 4 incelendiğinde Türkçe öğretmeni adaylarının 8’inin de görüş belirttiği görülmektedir. Türkçe öğretmeni adaylarının alıntı sözcüklerin hangi dilden geldiğini belirlemede en sık başvurdukları yollar televizyon ve sinema, dinî terimlerdir. Bu yollar için üçer öğretmen adayı görüş bildirmiştir. Popüler kültür için 2, alıntı sözcük olarak Türkçede fazlaca yer alan dillerden geçen sözcükler için 1, eğitim dili hakkında 1, bilinen yabancı dilden hareketle belirleme, sosyal medya ve sözlük kullanma hakkında birer ve aldığı eğitim sayesinde bunları belirleme hakkında ise 2 Türkçe öğretmeni adayı görüş belirtmiştir. Dinî terimler, televizyon, sinema, popüler kültür ve alınan eğitimin alıntı sözcüklerin hangi dilden geldiğini belirlemede Türkçe öğretmeni adayları için başvurulan ilk yollar olduğunu ifade etmek mümkündür.

Alıntı sözcükleri belirlerken popüler kültürün yol göstericiliği hakkında belirtilen görüşler şu şekildedir: 
Ö.: Mesela j ve p’nin Fransızcaya ait olduğunu öğrendim. Başka dinî kelimeleri rahatça belirleyemiyorum. Popüler kültürün etkisiyle sözcükleri belirleyebiliyorum. Televizyondan bye bye gibi Batı dillerinden gelenleri belirleyebiliyorum.

$\ddot{O}_{4}$ : Bariz bir şekilde belli olanlar mesela dinî unsurların oldukları genelde Arapça oluyor. Ya da yeni günümüze uygulanmış modern olanlar popüler kültür. Modern olanı en çok kullanıyorum.

Televizyon ve sinemanın aracılığı ile alıntı sözcükleri belirleyebilen Türkçe öğretmeni adaylarının görüşleri ise şöyledir:

$\ddot{O}_{5}$ : Çok yabancı film izlerim Fransızca, İspanyolca, Almanca, İngilizce kelimeleri söylenişine göre birbirinden ayırt edebilirim. Ses özelliklerini dikkate alıyorum. Ses özelliklerine göre ayırt etmeye en çok başvuruyorum. Ağız özelliklerini de kullanırım.

Ö$_{7}$ : Yani öyle karşılıklı konuşmalarda direkt belirleyemem önceden de dediğim gibi yazı dilinde bu fark edilir. Dinî metinse Arapça olduğunu düşünüyorum. Televizyonlarda gördüğüm bir kelimeyi ise Batı kökenli olduğu yönünde fikir üretiyorum.

Din vasitasıyla Türkçeye giren sözcükleri alıntı sözcük belirleme yolu olarak kullananlardan biri görüşünü şu şekilde ifade etmiştir:

Ö$_{3}$ : Hangi dilden geldiğini belirleme, dinî terimlerden geçen kelimeler, Arapça veya bildiğim hani İngilizceyi az çok biliyorum mesela o dilden geçmişse anlayabiliyorum.

Üniversitede görülen dersler ve alınan eğitim sayesinde alıntı sözcükleri belirleyebilenler görüşlerini şöyle bildirmiştir:

$\ddot{O}_{5}$ : Derslerden öğrendiğim kadarıla bazı örnekler verebilirim.

Ö6: İngilizceyi daha çok hani yazımına göre fark ediyorum. Arapça ve Farsçayı da ağız özelliklerine göre. Ya da bildiğim kelimeler olur bu Arapçadır. Genel olarak da derslerden bildiğim bu Arapça kelimedir. Daha çok ağız özelliklerini kullanıyorum.

\subsection{Türkçe öğretmeni adaylarının alıntı sözcüklerin yerine Türkçe kökenli eş anlamlılarını kullanma hakkındaki görüşlerine dair bulgular}

Bazı alıntı sözcükler dilde karşıllğı olmasına rağmen dile girmektedir. Bu bölümde Türkçe öğretmeni adaylarının bu tür sözcüklere ilişkin, alıntı sözcüğü mü yoksa Türkçe eş anlamlısını mı kullanmak gerektiğine dair görüşleri incelenmiştir.

Tablo 5: Türkçe öğretmeni adaylarının alıntı sözcüklerin yerine Türkçe kökenli eş anlamlılarını kullanma hakkındaki görüşleri

\begin{tabular}{ll}
\hline Alıntı sözcüklerin yerine Türkçe kökenlilerini kullanma & f \\
\hline Dikkat etme $\ddot{O}_{1}, \ddot{\mathrm{O}}_{4}, \ddot{O}_{5}, \ddot{\mathrm{O}}_{7}, \ddot{O}_{8}$ & 5 \\
\hline Türkçeleşmiş olanları ayırt etmeden kullanma $\ddot{\mathrm{O}}_{2}, \ddot{\mathrm{O}}_{7}$ & 2 \\
\hline Yeni alıntı sözcükleri kullanmama $\ddot{\mathrm{O}}_{2}$ & $\mathbf{1}$ \\
\hline Türkçe ses yapısına uyumu $\ddot{O}_{3}$ & $\mathbf{1}$ \\
\hline Resmî yazılarda önem verme $\ddot{O}_{6}$ & $\mathbf{1}$ \\
\hline
\end{tabular}

Tablo 5 incelendiğinde Türkçe öğretmeni adaylarının 8’inin de görüş belirttiği görülmektedir. Türkçe öğretmeni adaylarının alıntı sözcüğün Türkçe eş anlamlıları varsa bunu kullanmaya özen gösterdiği dikkat çekmektedir. Buna dikkat ettiğini 5 öğretmen adayı bildirmiştir. 2 öğretmen adayı ise artık Türkçeleşmiş olanların böyle bir muameleye tabi tutulmaması gerektiğini belirtmiştir. Yeni alıntı 
sözcüklerin kullanılmaması gerektiği bunlar için Türkçe karşılıklar bulma çalışmaları yapılması gerektiği, Türkçe ses yapısına uyum göstermişse bunun kullanılmasında sakınca olmadığı ve resmî yazılarda da Türkçe kökenlilerin kullanılmasına dikkat edilmesi gerektiği hakkında birer öğretmen adayı görüşlerini aktarmıştır.

Alıntı sözcükler yerine Türkçe eş anlamlılarını kullanmaya dikkat eden Türkçe öğretmeni adaylarından bazılarının görüşleri şu şekildedir:

Ö.: Böyle bir geri dönüş yapmıyorum yazarken ama konuşurken Türkçesini kullanmaya daha fazla dikkat ederim.

$\ddot{O}_{4}$ : Konuşurken dikkat edemiyorum ama yazarken dikkat etmeye çalışıyorum. Ve öyle olması gerektiğini düşünüyorum. En azından yazı dilimizde dikkat etmemiz gerektiği fikrindeyim. Yazı yazarken kullandığım bir sözcüğün bariz bir şekilde yabancı kökenli olduğunu fark ettiğimde bunu silip bunun yerine Türkçe kökenli olanını yazmayı tercih ediyorum.

$\ddot{O}_{5}$ : Türkçesi varken yabancı kökenli olanının kullanılmaması gerektiğini düşünüyorum. Yazarken özellikle Türkçe kökenlisi varsa bunu yazmaya dikkat ediyorum.

Türkçeleşmiş olanların ayırt edilmeden kullanılması gerektiği hakkında bildirilen görüşlerden biri şöyledir:

Ö.: Şimdi şu konudaki düşüncem Ziya Gökalp Ali Canip Yöntem ve Ömer Seyfettin’in Yeni Lisandaki düşünncelerini ben de onayliyorum. Türkçeleşmiş Türkçedir. Yani bugün kitap sözcüğü biz de eski Türkçede bitig yanlış hatırlamıyorsam atasözlerimize deyimlerimize mal olmuş sözcükler yerine Türkçe kökenli sözcüklerin kullanılmasına pek taraftar değilim. Ama tabi ki de yeni giren sözcüklere çalışmalar yapılabilir ama sırf Türkçe olacak diye eskileri değiştirmeye kalkmak dili katletmeye giriyor.

Alıntı sözcükler yerine Türkçe kökenli eş anlamlılarının resmî yazılarda kullanılması gerektiği hakkında görüş bildiren Türkçe öğretmeni adayının görüşleri şunlardır:

Ö6: Konuşurken genelde çok hızlı konuştuğum için fark edemiyorum. Çok çok sonradan aklıma gelirse o konuşma belki fark ederim. Yazarken de yazma zamanına göre değişiyor. Mesela mesaj yazarken dikkat etmem. Herhangi bir ödev olsun veya herhangi üst düzey bir makama dilekçe tarzı mesaj olsa dikkat ederim. Ama arkadaşlarımla yazışırken çok da geriye dönüşlerim olmuyor.

\subsection{Türkçe öğretmeni adaylarının alıntı sözcüklerin alındıkları dildeki gibi kullanımı hakkındaki görüşlerine dair bulgular}

Alıntı sözcükler, çoğunlukla dillerin kendi ses yapılarına uydurulur. Ancak bazen de bu durumla karşlaşılmaz ve dile asıl şekilleriyle girerler. Bu tür alıntı sözcükler hakkındaki Türkçe öğretmeni adaylarının görüşleri bu bölümde incelenmiştir.

Tablo 6: Türkçe öğretmeni adaylarının alıntı sözcüklerin alındıkları dildeki gibi kullanımı hakkındaki görüşleri

\begin{tabular}{ll}
\hline Alıntı sözcükklerin alındıkları dildeki gibi kullanımı & f \\
\hline Alındıkları dildeki gibi kullanılma $\ddot{O}_{1}$ & 1 \\
\hline Ek getirme $\ddot{O}_{2}, \ddot{O}_{4}$ & 2 \\
\hline Türkçe karşıllı bulma $\ddot{O}_{3}, \ddot{O}_{7}$ & 2 \\
\hline Söylenişi / yazılışı Türkçeleştirme $\ddot{O}_{5}, \ddot{O}_{6}$ & 2 \\
\hline Türk Dil Kurumunu takip etme $\ddot{O}_{8}$ & 1 \\
\hline
\end{tabular}


Tablo 6 incelendiğinde Türkçe öğretmeni adaylarının 8’inin de görüş belirttiği görülmektedir. Türkçe öğretmeni adaylarından 1’i sözcüklerin bu şekilde kullanılmasında bir sıkıntı olmadığını ifade etmiştir. 2 öğretmen adayı bu sözcüklere ek getirilmesi, 2 öğretmen adayı da bunların yazılışlarının / söylenişlerinin Türkçeleştirilmesi gerektiğini bildirmiştir. Yine Türkçe öğretmeni adaylarından 2'si Türkçe karşllıklar bulunması; 1’i de Türk Dil Kurumunun bu konudaki çalışmalarının takip edilmesi gerektiğini söylemiştir. Türkçe öğretmeni adaylarının alıntı sözcüklerin alındıkları dildeki gibi kullanılmasının önüne geçilmesi gerektiği görüşünde olduğunu söylemek mümkündür.

Alıntı sözcüklerin alındıkları dildeki gibi kullanılması gerektiğini belirten Türkçe öğretmeni adayı görüşünü şöyle ifade etmiştir:

Ö.: Türkçe karşılığı bulunamadığı için bunlar yerleşmiş. Bunlara ek vs. getirilmemeli bu kelimeler olduğu gibi alınmalı bence.

Alıntı sözcükler Türkçeye girerken bunlara ekler getirilmesi gerektiği görüşünde olanların ifadeleri şöyledir:

$\ddot{O}_{2}$ : Mesela çikolata kelimesinin İngilizcesi okunuşu çikolata gibi geliyor herhangi bir farklılık yaratmıyoruz. Bu doğru mu? Olmayabilir. En azından bizim de dilimizden bir şeyler katarak onu Türkçeleştirebiliriz. Bunu engellemek için ekler ekleyebiliriz.

$\ddot{O}_{4}$ : Mesela pardon Fransızcada olduğu gibi kullanılıyor. Bu kelimeyi kendi ses yapımıza uydurmamız zor olur. Ama ekler getirerek biraz da olsa dilimize benzetiriz.

Alıntı sözcüklerin Türkçedeki kullanımı yaygınlaşmadan önce bunlar için Türkçe karşlıklar bulunması gerektiğini belirtenlerin görüşleri ise şöyledir:

Ö$_{3}$ : Türkçe yani çok fazla olmamakla birlikte bazı kelimelerde dikkatimi çekiyor. Sosyal medyada dikkatimi çekiyor. Televizyonlarda "talk show" gibi. Aslında mesela hani "selfie" çıktı ya çıkar çıkmaz "öz çekim” deseydiler "öz çekim” olarak kalırdı ama belli bir süre geçti aradan herkes "selfie” dedi sonra onu "öz çekim" yapmak zor oluyor. Çıkar çıkmaz hemen bir karşılık bulmak gerektiğini düşünüyorum.

Ö$_{7}$ Bunlar elbette dikkatimi çekiyor. Çünkü ana dilim değil. Hani farklı bir dilden geldiği açıkça ortada kullanmasak daha iyi olur. Engellemek için bence dil gelişiminin en önemli safhası çocukluktur. Bu yüzden çocuk yaşlarda bu altyapıyı oluşturmalıyız çocuklarımızda ki ileriki yaşlarda güçlük çekmesinler. Hani yabancı dillere karşı böyle bir sempati beslemesinler. O yüzden en önemlisi çocukluk yaşlarıdır. Bu yüzden eğitimi orada vermeliyiz.

Sözcüklerin yazılışlarının / söylenişlerinin Türkçeleştirilmesi gerektiğini ifade edenlerin görüşleri şunlardır:

$\ddot{O}_{5}$ : Bunlar dikkatimi çekiyor ama bir noktadan sonra mesela "inisiyatif" "iniative"den geliyor. Biz bunu Türkçeleştiriyoruz öyle söylüyoruz ama bir noktadan sonra çok farklı gelmiyor bana. Ayrıcalık desek daha güzel olur ama söylenişine göre Türkçeleştirmek evet iyi bir şey. Kolay oluyor. Ya İngilizce kelimeyi Türkçe özelliklere göre yazmalıyı ya da Türkçesini kullanmalıyız.

Ö6: Bunu hani kullanılmaması gerektiğini düşünüyorum. Bunun özgünlüğü bozduğunu düşünüyorum. Bir Türkün İngilizce bir kelimeyi aynı șekilde alması ya da bir İngiliz'in Türkçe bir kelimeyi aynı şekilde alması özgünlüğü bozuyor. O şekilde almamız doğru değil diye düşünüyorum. Bizim kendimize göre onu uyarlamamız lazım ve bir özgünlük kazandırmamız lazım.

$\mathrm{Bu}$ sözcükler için yapılması gerekenlerin Türk Dil Kurumu tarafından yapıldığını ve Türk Dil Kurumunun çalışmalarının takip edilmesi gerektiğini ifade eden Türkçe öğretmeni adayı görüşlerini şu şekilde bildirmiştir: 
Ös: Evet dikkatimi çekiyor. Bu konuda görev bence Türk Dil Kurumuna düşüyor. Eski sözcükleri yeniden canlandıran anlamını kaybedenlere yeniden anlam kazandıran da Türk Dil Kurumu. Yapabileceğimiz tek şey Türk Dil Kurumunun çalışmalarını takip etmek.

\subsection{Türkçe öğretmeni adaylarının alıntı sözcüklerin yazımlarının karıştırılmaması için neler yapılabileceği hakkındaki görüşlerine dair bulgular}

Alıntı sözcüklerin özellikle Türkçe ses yapısına uymayan özellikleri bulunduğundan Türkçede yazımlarında zorluklarla karşılaşılmaktadır. Bu bölümde Türkçe öğretmeni adaylarının alıntı sözcüklerin yazımlarının karıştırılması hakkındaki görüşleri ele alınmıştır.

Tablo 7: Türkçe öğretmeni adaylarının alıntı sözcüklerin yazımlarının karıştırılmaması için neler yapılabileceği hakkındaki görüşleri

\begin{tabular}{ll}
\hline Alıntı sözcüklerin yazımlarının karıştırılmaması & f \\
\hline Sosyal medya kullanma $\ddot{O}_{1}, \ddot{O}_{2}$ & 2 \\
\hline Kurslar gerçekleştirme $\ddot{O}_{1}, \ddot{O}_{3}, \ddot{\mathrm{O}}_{7}$ & 3 \\
\hline Hizmet içi eğitim verme $\ddot{O}_{4}, \ddot{\mathrm{O}}_{5}, \ddot{O}_{8}$ & 3 \\
\hline Metin kullanma Ö & 1 \\
\hline
\end{tabular}

Tablo 7 incelendiğinde Türkçe öğretmeni adaylarının 8’inin de görüş belirttiği görülmektedir. Türkçe öğretmeni adaylarından 2'si sosyal medya kullanarak doğru kullanımların öğretilebileceği görüşünü dile getirmiştir. Üçer Türkçe öğretmeni adayı da doğru yazım konusunda kurslar gerçekleştirilebileceğini ve tüm öğretmenlere hizmet içi eğitim verilebileceğini ifade etmişlerdir. 1 Türkçe öğretmeni adayı ise bu sözcüklerin geçtikleri metinlerden yararlanılması gerektiğini söylemiştir.

Sosyal medya kullanarak bu sözcüklerin doğru yazımlarının yaygınlaştırılabileceğini belirten Türkçe öğretmeni adayları şunları ifade etmişlerdir:

Ö.: Bunların önüne geçmek için mesela ben diksiyon dersi aldım. Orada çok gördüm bunları. İnisiyatif, mütevazı. Sınavda da onlara tabi olduk doğrularını yazın demişlerdi. Başka mesela bunlar sosyal medyada da güzel bir şekilde kullanılabilir. Televizyonda mesela haber spikerleri fazla dikkat etmiyor. Bazıları önerse de bazı hocalar da konuşamıyorlar diyorlar. Kurslar verilerek bunun önüne geçilebilir. Türkçe öğretmenleri için ekstradan bir ders veya kurs geliştirilebilir.

$\ddot{O}_{2}$ : Bu dil bilinciyle de alakalı bir şey. Derslerde bunu daha çok ön plana çıkartabiliriz. Öğrencilerin dikkatini daha çok çekebilecek sosyal medyayı daha ön plana çıkarabiliriz. O şekilde bir şuur yaratılabilir.

Hizmet içi eğitimler verilerek bu kullanımların düzeltilmesi gerektiğini belirten Türkçe öğretmeni adaylarının görüşlerinden birisi şu şekildedir:

$\ddot{O}_{4}$ : Derslerimizde buna ağırlık vermemiz gerekiyor. Türkçe öğretmenliği okuyoruz öğrencileri bilinçlendirmeliyiz. Müfredatı değiştirmeliyiz ya da. Öğretmenler için hizmet içi eğitim verilebilir. Bunu farklı ders öğretmenleri için de verebiliriz. Çünkü her derste Türkçe kullanıyoruz.

Bu sözcüklerin doğru yazımlarının öğretilmesi hususunda sözcüklerin geçtikleri metinlerin kullanılması gerektiğini ifade eden Türkçe öğretmeni adayının görüşleri şu şekildedir:

Ö6: Bunun için kelimeleri alırken kendi ses özelliklerimizi kelimeye uygulayabiliriz. Öğrencilere bu kelimelerin ayrımını fark ettirip anlamlarını iyice belletmeliyiz. Bunun için de o kelimelerin geçtiği metinlere başvurabiliriz. Metinlerden anlamlarına bakabiliriz ya da başka bunun hakkında pek bir çözüm yolu bulamadım. 


\subsection{Türkçe öğretmeni adaylarının alıntı sözcükler söylenirken yaşanan zorluklar için neler yapılabileceği hakkındaki görüşlerine dair bulgular}

Alıntı sözcüklerde özellikle kaynak dildeki kullanımıyla dile girenlerde söylerken zorluklarla karşılaşılmaktadır. Bu bölümde alıntı sözcüklerin söylenişinde yaşanan zorluklar hakkındaki görüşlere yer verilmiştir.

Tablo 8: Türkçe öğretmeni adaylarının alıntı sözcükler söylenirken yaşanan zorluklar için neler yapılabileceği hakkındaki görüşleri

\begin{tabular}{ll}
\hline Alıntı sözcüklerin zor söylenişleri & $\mathrm{f}$ \\
\hline Kitap okuma $\ddot{O}_{1}$ & 1 \\
\hline Yazım kılavuzu kullanma $\ddot{O}_{1}$ & 1 \\
\hline Türkçe karşılık bulma $\ddot{O}_{2}, \ddot{O}_{3}, \ddot{O}_{4}$ & 3 \\
\hline Telaffuz çalışmaları yapma $\ddot{O}_{5}, \ddot{O}_{6}, \ddot{O}_{8}$ & 3 \\
\hline Konferans gerçekleştirme $\ddot{O}_{7}$ & 1 \\
\hline Kamu spotu hazırlama $\ddot{O}_{7}$ & 1 \\
\hline
\end{tabular}

Tablo 8 incelendiğinde Türkçe öğretmeni adaylarının 8’inin de görüş belirttiği görülmektedir. Türkçe öğretmeni adaylarından 1'inin bu söylenişlerdeki zorluğun önüne geçmek için kitap okunması ve yazım kılavuzu kullanılması, 1’inin de konferanslar gerçekleştirilmesi ve kamu spotlarının televizyonlarda yayınlanması gerektiği yönünde görüş bildirdiği görülmektedir. Türkçe öğretmeni adaylarından 3 ’ü Türkçe karşılıklar bulunması, 3’ü de telaffuz çalışmaları yapılmasına özen gösterilmesi hususunda dikkatli davranılması yönünde görüş bildirmişlerdir.

Alıntı sözcüklerin söylenişlerindeki zorlukların önüne geçmek için kitap okunması ve yazım kılavuzu kullanılması gerektiğini belirten Türkçe Öğretmeni adayı görüşlerini şöyle bildirmiştir:

Öı: Özellikle Anadolu'da çok fazla. Köylerde. Anında düzeltme gereklidir. Kitap okunması gerektiğgini düşünüyorum. Dili geliştirmek için dediğim gibi çok fazla kitap okumak bir de sözcüklerin doğru telaffuzunu bilmek çok önemli. Hatta birinden duyuyoruz profiterol diyor mesela hani bunu öğreneyim demek ki bu doğru diyoruz. Başka birinden başka bir şey duyuyoruz aslında bunu yazım klavuzuna bakarak doğrusunu araştırarak da bulabiliriz.

Söylenirken zorluk yaşanan alıntı sözcükler için Türkçe karşılıklar bulunması gerektiğini belirten Türkçe öğretmeni adaylarının görüşleri şöyledir:

$\ddot{O}_{2}$ : Ya bunları mesela Türkçeleştirilmiş hâlleri alzaymır yerine unutkanlık hastalığı ve bunları yaygınlaştırabiliriz. Bunlara Türkçe isimler koyabiliriz. Bu basit bir şey ama önemli olan bunu işleve geçirebilmek. Günümüz gençlerine ise İngilizce kelimeler daha çekici geliyor. Böyle bir kaygımız yok. Türkçe karşıılık bulsak bunun kullanılacağını da sanmıyorum.

$\ddot{O}_{3}$ : Aslında en güzel hani alıntı kelimenin olmaması varsa ne bilim o tarz sözcükler Türkçeleştirilmeli. Zamanla değiştirilmeli. Türkçenin ses özelliklerine göre değiştirmek. Kullanıldığı yerde karşıllğını bulmaya çalışmalıyız.

$\ddot{O}_{4}$ : Toplum düzeyine en fazla mesela herkesin anlayabileceği şekilde daha basit bir karşıllı̆̆ getirilmeli toplumun eğitim düzeyi de göz önüne alınarak. Böylece toplumun her kesimi de kullanabilir o kelimeyi.

Bu sözcüklerin söylenmesindeki zorlukların önüne geçmek için telaffuz çalışmaları yapılması gerektiğini düşünen Türkçe öğretmeni adaylarının görüşleri şu şekildedir: 
Ö : Bence bu kelimeleri çok görmekle alakalı. Delalet ve dalalet kelimelerini ayırt etme de önemli burada tek harften dolayı anlam da değişiyor. Çok görmekle alakalı. Üniversitelerde ses özellikleri ile ilgili çalışmalar yapılmalıdır.

Ö6: Doğru telaffuz çalışmaları yapılması gerekiyor. Hani kelimenin üzerinde özellikle biz sık sık yaparız. Kalemle bir çalışmamız var bunu derste de çok yaparız. Kalemi ağzımıza alarak yaparız. Bu tür yolların çoğaltılması gerekiyor diye düşünüyorum.

Ös: Boğumlama noktasında sıkıntılar yaşıyoruz. Bu sözcüklerin anlam farklılıklarını belirtmek için farklı çalışmalar yapacağız, insanlarda bir farkındalık oluşturacağız. Burada görev en başta eğitimcilere düşer. Anlam farklılıklarının öğretilmesi için sözcük çalışmalarında anlamı verip geçmektense sözcüklerle ilgili karşılaştırmalı etkinliklere yer verilmelidir.

Alıntı sözcükler söylenirken yaşanan zorlukların önüne geçmek için konferanslar verilmesi ve televizyonlarda kamu spotu yayınlanması gerektiğini düşünen Türkçe öğretmeni adayının görüşleri ise şunlardır:

Ö : Mesela küçük küçük mesela konferanslar yapılabilir. İnsanlar bu konuda bilinçlendirilebilir insanlarımız doğru telaffuzlarda. Televizyonlarda haber spikerlerimiz olsun diğer spikerlerimiz olsun daha dikkatli davranabilirler. Daha dikkatli konuşabilirler bu noktada. Çünkü bizim Türk toplumunda günümüzün büyük bir bölümü yanlış bilmiyorsam televizyon izleyerek geçiriyoruz kitapları çok az okuyoruz. Televizyonlara çok fazla görev düşmektedir. Örneğin: Sigaranın zararı konusunda bir kamu spotu yayınlanıyorsa televizyonlarda dil de çok önemli. Dilimiz hakkında farkındalık yaratmak için televizyonlarda kamu spotları kullanılabilir.

\subsection{Türkçe öğretmeni adaylarının alıntı ve yabancı sözcüklerin ağırlıkla kullanılması hakkındaki görüşlerine dair bulgular}

Farklılık oluşturma, özenti gibi nedenlerden dolayı Türkçede kullanımı yaygınlaşmayan alıntı sözcükler, alıntı sözcüklerle kurulan tamlamalar ve dilde henüz karşılığı bulunmayan yabancı kavramlarla konuşma hakkındaki Türkçe öğretmeni adaylarının görüşlerine bu bölümde yer verilmiştir.

Tablo 9: Türkçe öğretmeni adaylarının alıntı ve yabancı sözcüklerin ağırlıkla kullanılması hakkındaki görüşleri

\begin{tabular}{|c|c|}
\hline Alıntı ve yabancı sözcüklerin ağırlıkla kullanımı & $\mathbf{f}$ \\
\hline Dili yozlaştırma $\ddot{O}_{1}, \ddot{O}_{6}$ & 2 \\
\hline Samimiyetsizlik $\ddot{O}_{2}$ & 1 \\
\hline Uyarma $\ddot{O}_{3}$ & 1 \\
\hline Denetim $\ddot{O}_{3}, \ddot{O}_{8}$ & 2 \\
\hline Bilinçlenme $\ddot{O}_{4}$ & 1 \\
\hline Özenti $\ddot{O}_{5}$ & 1 \\
\hline İlgi çekicilik $\ddot{O}_{7}$ & 1 \\
\hline
\end{tabular}

Tablo 9 incelendiğinde Türkçe öğretmeni adaylarının 8’inin de görüş belirttiği görülmektedir. Türkçe öğretmeni adaylarından 2'si bu tarz kullanımların dili yozlaştırdığı, 2'sinin bunların denetlenmesi gerektiği, birer öğretmen adayının samimiyetsizlik, uyarma bilinçlenme özenti ve bu tarz kullanımların ilgi çekici olduğu yönünde görüş bildirdikleri görülmektedir.

Bu tarz kullanımların dili yozlaştırdığı hakkında bildirilen görüşler şunlardır:

Ö.: Ben yaşadığım çevrede zaten bir köy yaşantım var benim. Alıntı sözcüklerle kurulmuş bir dil yok bozulmamıș ağızlar var. Türkçenin en eski șekilde bozulmamıș şeyleri var. Bazen eski bir sey söylüyorlar bunu da ben anlamıyorum mesela. Bunu araştırma gereği duyuyorum ama yeni nesilde 
de gençler arasında İngilizce konuşma merakı biraz daha fazla. Moda olsun diye mi bilmiyorum. Bunu doğru karşılamıyorum dili yozlaştırıyor.

Ö6: Bunu hiç olumlu karşılamıyorum. Çünkü dil bozulunca kültürümüz her şey bozulur. Her şeyin dille başladığını düşünüyorum. Belli bir kimliğimiz var ve kullandığımız o yabancı kelimeler dilimize zarar veriyor, kimliğime zarar veriyor ve dilimizden sonra kültürümüze zarar veriyor. Gitgide bu yollar birbirini çoğaltıyor. Bu yüzden dilin her şeyin başlangıcı olduğunu düşünüyorum. Bunu kesinlikle onaylamıyorum.

Alıntı ve yabancı sözcüklerin ağırlıklı olarak kullanımının uyarma ve denetim ile önüne geçilmesi gerektiği hakkında görüş bildiren Türkçe öğretmeni adayları şunları dile getirmişlerdir:

$\ddot{O}_{3}$ : Başkası kullanırken daha Türkçe kelime kullanmasını isterim. Uyarırım ama elimden başka bir şey gelmez. Programlarda artık RTÜK'ün belli bir mercinin bunu denetime alması ve daha az yabancı kelimenin kullanılmasını teşvik etmesi gerekmektedir.

Ös: Bence RTÜK olsun TRT olsun neden bu tarz konuşmalara yer veriyor. Sonuçta sanatçılar toplumu eğitimciler kadar olmasa da bir noktada geliştirecek kişiler. Bunların konuşmalarının radyo ve televizyonlarda uyarıya tabi tutulmadan verilmesi bence sorun. Bunların Türkçeyi düzgün kullanmaları gerekiyor. Çünkü bunlar toplumu yönlendirecek kişiler.

Bu sözcüklerin kullanımlarının ilgi çekici olduğu ve bunların doğrusunun nasıl olması gerektiği hakkında farkındalık oluşturduğunu belirten Türkçe öğretmeni adayının görüşleri şunlardır:

Ö$:$ Ben bunları ilgi çekici olarak karşılıyorum. Olumlu yanından bakmayı düşünüyorum. En azından bir farkındalık yaratıyor bizlerde. Hani bu kelime böyle kullanılmaz. Ben bunu görüyorum yani. O insanlar o kelimeyi o şekilde kullandığı zaman ben diyorum ki o kelimeyi öyle kullanmayacağım ben. Bana yardımcı oluyor yani.

\subsection{Türkçe öğretmeni adaylarının alıntı sözcüklerin ağırlıkla kullanıldığı metinleri anlamakta yaşanan zorluklar hakkındaki görüş̧lerine dair bulgular}

Yine Türkçede kullanımı yaygınlaşmamış, dilde sadeleşme dönemlerindeki çalışmalarla dildeki kullanım oranı düşürülerek dilde pasif hâle getirilmiş olan sözcüklerle roman, şiir, hikâye, deneme $v b$. türlerde karşılaşılmaktadır. Bu tarz sözcüklerin yoğunlukla kullanıldığı metinlerin anlaşılmasında yaşanan zorluklar hakkındaki Türkçe öğretmeni adaylarının görüşleri bu bölümde incelenmiştir.

Tablo 1o: Türkçe öğretmeni adaylarının alıntı sözcüklerin ağırlıkla kullanıldı̆̆ı metinleri anlamakta yaşanan zorluklar hakkındaki görüşleri

\begin{tabular}{ll}
\hline Alıntı sözcüklerin ağırlıkla kullanıldığı metinleri anlamada yaşanan zorluklar & f \\
\hline Roman ve hikâyelerin anlaşılmaması $\ddot{\mathrm{O}}_{1}, \ddot{\mathrm{O}}_{5}, \ddot{\mathrm{O}}_{6}$ & 3 \\
\hline Şiirleri anlama zorluk çekme $\ddot{\mathrm{O}}_{2}, \ddot{\mathrm{O}}_{7}, \mathrm{O}_{8}$ & 3 \\
\hline Sağllkla ilgili metinler $\ddot{\mathrm{O}}_{3}$ & $\mathbf{1}$ \\
\hline Bilimsel metinlerde zorluk çekme $\ddot{\mathrm{O}}_{4}$ & $\mathbf{1}$ \\
\hline Dipnot verme $\ddot{\mathrm{O}}_{4}, \ddot{\mathrm{O}}_{5}$ & $\mathbf{2}$ \\
\hline Makale ve köşe yazılarında zorluk çekme $\ddot{O}_{6}$ & $\mathbf{1}$ \\
\hline
\end{tabular}

Tablo 10 incelendiğinde Türkçe öğretmeni adaylarının 8’inin de görüş belirttiği görülmektedir. Türkçe öğretmeni adaylarının roman, hikâye ve şiirlerde bu tarz kullanımlarla karşılaştıkları ve bunları anlamakta zorluk çektikleri görülmektedir. Bunun için 6 öğretmen adayı görüş bildirmiştir. Sağlıkla ilgili metinlerde, bilimsel metinlerde ve köşe yazılarında bu zorlukla birer Türkçe öğretmeni adayı karşılaştığını belirtmiştir. 2 öğretmen adayı da bu tarz metinlerde dipnotlar aracıllğı ile anlamı vermeye ilişkin görüşlerini dile getirmiştir. 
Roman ve hikâyelerdeki bu tarz kullanım hakkında Türkçe öğretmeni adaylarının dile getirdiği görüşlerden bazıları şunlardır:

Ö.: Bu tarz metinleri anlamakta zorlanıyorum. Romanlar, hikâyelerde rastladığım bir durum.

$\ddot{O}_{5}$ : Yaşıyorum mesela Tanzimat Dönemi romanlarında Fransızca kelimeler numaralandırma ile altında yazar. Bu kitapları okurken zorlanırım. Bunun dışında da makalelerde geçen çok sayıda yabancı kökenli kelimeler vardır. Bir noktadan sonra bunları anlamak bende kopar. Denemelerde de aynı şeyi yaşıyorum.

Şiirlerdeki bu tarz kullanım hakkında Türkçe öğretmeni adaylarının dile getirdiği görüşlerden bazıları şunlardır:

$\ddot{O}_{2}$ : Tabi tabi. Bizim özellikle Osmanlıca derslerimiz var Tevfik Fikret’in bazı şiirlerini gerçekten anlamıyoruz. Yani evet şiirin anlamı gerçekten çok yüklü ama daha yazılalı 100 sene olduğu hâlde pek anlam veremiyoruz yani anlamiyoruz.

$\ddot{O}_{7}$ : Tabi ki de anlamakta zorluk yaşıyorum. Zorlandığım yerlerde de direkt sözlüğe bakıyorum. Mesela Divan Edebiyatı’nda daha çok İran kültüründen etkilendiğimiz için orada Farsça sözcükler yoğunlukta. Onları anlamakta zorlanıyorum. Tabi Arapçayı, Farsçaya göre dilimizde daha fazla benimsemişiz. Bu yüzden Arapça sözcükleri daha rahat seçebiliyorum.

Dipnotlar verilerek bu tarz sözcüklerin anlamlarının açıklanması hakkındaki Türkçe öğretmeni adaylarının dile getirdiği görüşlerden biri şöyledir:

$\ddot{O}_{4}$ : Mesela bazı kitaplarda altta anlamı oluyor. Mesela yıldız koyup dipnot veriyorlar. Bunu oraya yazmaktansa metnin içinde vermeliler. Romanlarda ve bilimsel metinlerde zorluk yaşıyorum.

Makale ve köşe yazılarında bu konu ile ilgili orak yaşanan zorlukları 1 Türkçe öğretmeni adayı şu şekilde dile getirmiştir:

Ö6: Evet zorluk yaşıyorum. Özellikle hatta anlamlarına bakmakta üşeniyorum. O yüzden ben de genellikle tercih etmiyorum. O tür metinleri bırakıyorum. Bu tarz metinlerle daha çok makalelerde karşlaşıyorum. Ya da bazı yazarların kitaplarında daha çok karşılaşıyorum. Günümüz yazarlarında romanlarında çok karşılaşıyorum. Gazetelerin köşe yazılarında da çok karşılaşıyorum. Facebook yazılarında falan da karşılaşıyorum. Günümüzde birçok yerde karşılaşıyorum bu tür yazılarla.

\subsection{Türkçe öğretmeni adaylarının bilmedikleri alıntı sözcüklerin anlamlarını araştırma hakkındaki görüşlerine dair bulgular}

Anlamı bilinmeyen bir alıntı sözcükle karşılaşıldığında anlamının araştırılması ve bunun için hangi kaynaklara başvurulduğu hakkındaki Türkçe öğretmeni adaylarının görüşlerine bu bölümde yer verilmiştir.

Tablo 11: Türkçe öğretmeni adaylarının bilmedikleri alıntı sözcüklerin anlamlarını araştırma hakkındaki görüşleri

\begin{tabular}{ll}
\hline Bilinmeyen alıntı sözcüklerin anlamlarını araştırma & f \\
\hline Google translate $\ddot{O}_{1}$ & $\mathbf{1}$ \\
\hline$T D K$ internet sayfası $\ddot{\mathrm{O}}_{1}, \ddot{\mathrm{O}}_{2}, \ddot{\mathrm{O}}_{4}$ & 3 \\
\hline İnternet $\ddot{\mathrm{O}}_{3}, \ddot{\mathrm{O}}_{5}, \ddot{\mathrm{O}}_{6}, \ddot{\mathrm{O}}_{7}, \ddot{\mathrm{O}}_{8}$ & 5 \\
\hline Türkçe Sözlük $\ddot{\mathrm{O}}_{3}, \ddot{\mathrm{O}}_{5}, \ddot{\mathrm{O}}_{6}, \ddot{\mathrm{O}}_{8}$ & 4 \\
\hline Uzman birisine danışma $\ddot{\mathrm{O}}_{6}$ & $\mathbf{1}$ \\
\hline
\end{tabular}


Tablo 11 incelendiğinde Türkçe öğretmeni adaylarının 8’inin de görüş belirttiği görülmektedir. Türkçe öğretmeni adaylarının anlamını bilmedikleri alıntı sözcüklerin anlamını araştırma eğilimi içinde oldukları görülmüsstür. Anlam araştırırken başvurdukları kaynaklar hakkında Google Translate için 1, TDK internet sayfası için 3, internet ortamı için 5, Türkçe Sözlük için 4, uzman birisine sorarak öğrenme için de 1 öğretmen adayı görüş bildirmiştir.

Google Translate, TDK internet sayfası ve internet ortamında sözcüklerin anlamını araştıranların görüşlerinden bazıları şunlardır:

Ö: Anlamına hemen bakarım. Bunun için daha çok Google Translate internet, özellikle Türk Dil Kurumunun internet sayfası, mesela diyelim perspektif gördüm, onu hemen perspektif TDK yazıyorum direkt ona göre geliyor. Yazım Kılavuzu'm var ama anlam için sözlük kullanmıyorum.

$\ddot{O}_{2}$ : Genelde şu var. Bizim dilimize Arapça ve Farsçadan çok sözcük girdiği için onları daha çok araştırmaya meyilliyim. Ama Fransızca, İngilizce olarak önüme koyulan sözcükleri pek araştırmıyorum açıkçası ama dilimizde artık kalıplaşmış bazı kelimeleri merak ediyorum. Türk Dil Kurumunun sitesi bu konuda benim için oldukça yeterli.

$\ddot{O}_{5}:$ Anlamını araştırırım. İnternetten bakarım. Sözlükten bakarım.

Türkçe Sözlük kullanarak sözcüklerin anlamını araştırdığını bildirenlerden bazılarının görüşleri şöyledir:

Ö$_{3}$ : Yeni duyduğum sözcüğün anlamını öğrenmek istiyorum. Bütün kelimeler için bunu yapmıyorum ama bazı kelimelerde öğrenmek isterim. Genelde yeni duymuşsam internetten araştırıyorum sözlük belki ikinci aşamam oluyor.

Ös: Araştırırım evet. Ben genelde sözlüğe bakıyorum. Türk Dil Kurumunun Sözlüğüne bakıyorum. İnternete bazen bakıyorum ama çok fazla bakmıyorum.

Yeni duyduğu veya anlamını bilmediği bir alıntı sözcüğün anlamını öğrenmek için alanında uzman birine başvuracağını belirten Türkçe öğretmeni adayının görüşleri şöyledir:

Ö6: Her zaman değil de bağlama göre değişiyor. Bazen araştırıyorum. İlk başvuru kaynağım internet oluyor daha kolay erişebildiğim için, orada bulamasam sözlük var orada da bulamasam bu konuda uzmanlaşmış kişilere soruyorum.

\subsection{Türkçe öğretmeni adaylarının Türkçesi varken yeni bir alıntı sözcüğün Türkçede yer alması hakkındaki görüşlerine dair bulgular}

Özellikle son dönemlerde yaygınlaşan Türkçesini kullanmak yerine sözcüğün yabancı bir dildeki karşılığının kullanılması ve Türkçeye yeni alıntı sözcüklerin girmesi hakkındaki Türkçe öğretmeni adaylarının görüşlerine bu bölümde yer verilmiştir.

Tablo 12: Türkçe öğretmeni adaylarının Türkçesi varken yeni bir alıntı sözcüğün Türkçede yer alması hakkındaki görüşleri

\begin{tabular}{|c|c|}
\hline Türkçesi varken yeni bir alıntı sözcüğün Türkçede yer alması & $\mathbf{f}$ \\
\hline Entelektüel görünme kaygısı $\ddot{O}_{1}, \ddot{O}_{5}$ & 2 \\
\hline Özenti $\mathrm{O}_{2}, \ddot{\mathrm{O}}_{6}, \ddot{O}_{8}$ & 3 \\
\hline Türkçeye giriş yollarının tespiti $\mathrm{O}_{4}$ & 1 \\
\hline Dil bilinci ile hareket etme $\ddot{O}_{7}$ & 1 \\
\hline
\end{tabular}


Tablo 12 incelendiğinde Türkçe öğretmeni adaylarının 7'sinin görüş belirttiği görülmektedir. Entelektüel görünme kaygısı için 2, özentiden dolayı bu tarz sözcüklerin Türkçeye girdiği yönünde 3, bu sözcüklerin Türkçeye giriş yollarının tespit edilerek bu tarz etkilere karşı daha korumacı olunması gerektiği için 1 ve dil bilinci ile hareket edilmesi, Türkçeyi böyle durumlara karşı korumak gerektiği hakkında da 1 öğretmen adayı görüş bildirmiştir.

Entelektüel görünme kaygısından dolayı bu tarz sözcüklerin Türkçede yer aldığını belirten Türkçe öğretmeni adaylarından birinin görüşü şu şekildedir:

Ö: Biz bunu aslında şimdi moda zannediyoruz. Yabancı kullanımları daha entelektüel zannediyoruz. Bu şekilde de Türkçeyi zorlaştırmış oluyoruz bir bakıma.

Özenti sebebiyle bu sözcüklerin Türkçede yer aldığını belirtenlerin görüşleri ise şöyledir:

Ö6: Bunun olmaması gerektiğini çünkü Türkçesi varken bașka dile başvurmak bu ihtiyaçtan doğmuyor. Bu tamamen onun farklılık yaratmak ya da kendini farklı bir şekilde göstermek. Çünkü yabancı bir kelime alırken belki Türkçesi yokken ihtiyaçtan alınabilir ama Türkçesi varken başka bir kelimeye ihtiyaç duyulmamalı. Diğer şekilde alınıyorsa ben farklı şekilde düşünürüm. Hani kendini farklı gösterme ya da Batı hayranlığı tarzında düşünürüm.

Ös: Bence bunu bizim insanımız daha fazla popüler olmak dikkat çekmek daha fazla kişi çekmek için kullanıyorlar diye düşünüyorum. Böyle yabancı bir sözcük kullandıklarında kendilerini daha iyi ifade edeceklerini daha bilgili görünebileceklerini düşünüyorlar bence bu yüzden kullanıyorlar. Bu durumu kesinlikle onaylamıyorum. Çünkü anlaşılmıyor.

Türkçede bu yolla yer almakta olan sözcüklerin önünü alabilmek için bu sözcüklerin Türkçeye giriş yollarının tespit edilmesi gerektiği yönünde görüş bildiren Türkçe öğretmeni adayı şunları belirtmiştir:

Ö 4 : Ben onun olmaması gerektiğini düşünüyorum. Türkçe karşılı̆̆ı varsa onu kullanmalıyız. Eğer girmişse kullanımını azaltabiliriz. Mesela nasıl yoldan girdi ona bir bakarız. $\mathrm{O}$ alanda mesela tıptan mı girmişo alanda daha çok çalışma yapıp Türkçe karşıllı̆ını kullanmayı teşvik etmeliyiz.

\subsection{Türkçe öğretmeni adaylarının alıntı sözcüklerin Türkçeye girmesinde etkili olan yollar hakkındaki görüsşlerine dair bulgular}

Yeni alıntı sözcüklerin Türkçeye girmesine neden olan yollar hakkındaki Türkçe öğretmeni adaylarının görüşlerine bu bölümde yer verilmiştir.

Tablo 13: Türkçe öğretmeni adaylarının alıntı sözcüklerin Türkçeye girmesinde etkili olan yollar hakkındaki görüşleri

\begin{tabular}{ll}
\hline Alıntı sözcüklerin Türkçeye girmesinde etkili olan yollar & f \\
\hline Sosyal medya $\ddot{O}_{1}, \ddot{O}_{2}, \ddot{O}_{3}, \ddot{O}_{4}, \ddot{O}_{6}, \ddot{O ̈}_{8}$ & 6 \\
\hline Arkadaşlarla kurulan iletişim $\ddot{O}_{1}$ & 1 \\
\hline Sinema $\ddot{O}_{1}, \ddot{O}_{2}, \ddot{O}_{6}, \ddot{O}_{7}$ & 4 \\
\hline Markalar $\ddot{O}_{1}, \ddot{O}_{6}$ & 2 \\
\hline Modaya uyma çabası $\ddot{O}_{1}, \ddot{O}_{4}$ & 2 \\
\hline Türk Dil Kurumunun çalışmalarının yetersizliği $\ddot{O}_{2}$ & 1 \\
\hline Televizyon $\ddot{O}_{3}, \ddot{O}_{7}$ & 2 \\
\hline Bilim Ö̈ & 1 \\
\hline Popüler kültür $\ddot{O}_{4}$ & 1 \\
\hline
\end{tabular}




\begin{tabular}{ll}
\hline Din $\ddot{O}_{5}$ & 1 \\
\hline Turizm $\ddot{O}_{6}$ & 1 \\
\hline Okunan kitaplar $\ddot{O ̈}_{6}$ & 1 \\
\hline Ticaret $\ddot{O}_{8}$ & 1 \\
\hline
\end{tabular}

Tablo 13 incelendiğinde Türkçe öğretmeni adaylarının 8’inin de görüş belirttiği görülmektedir. Türkçe öğretmeni adayları tarafından sosyal medya için 6, sinema için 4, markalar, modaya uyma çabası, televizyon için 2, arkadaşlarla kurulan iletişim, Türk Dil Kurumunun çalışmalarının yetersizliği, bilim, popüler kültür, din, turizm, okunan kitaplar ve ticaret için birer görüş bildirilmiştir.

Sosyal medya, sinema, televizyon ve popüler kültür için bildirilen görüşlerden bazıları şöyledir:

Ö.: Bana göre sosyal medya çok önemli, medya çok önemli ve özenti de çok önemli aslında. Arkadaşın sana bay bay yazinca sen de bir zamandan sonra Allah'a emanet ol yazamiyorsun sen de bay bay yazıyorsun. Arkadaş çevresi sosyal medya bunlar önemli oluyor. Sinema da var, markalar, modaya uyma bunlar da var.

$\ddot{O}_{2}$ : Şöyle bir olumsuzluk var. Birincisi Türk Dil Kurumunun yetersizliği. Demek ki yeni kelimeler şey yapamadığı için böyle şeyleri dil almak zorunda hissediyor. İki, toplum içinde sosyal medya. Sosyal medyada görülen bazı kelimeleri almak. En önemli iki etkenin bunlar olduğunu düşünüyorum. Sinemanın etkisi olabilir. Mesela "selfie" kelimesinin türemesi Oscar ödüllerinde çıtı. Tüm dünyanın takip ettiği bir program olduğu için tüm dünyanın içine girdi.

$\ddot{O}_{3}$ : Sosyal medya, televizyon, uluslararası yayınlar, bir de daha çok Batı özentisi gibi. İngilizceyi öğreniyor o dilden duyduğu öğrendiği şeyi günlük hayatta hemen kullanmaya çalışıyor.

$\ddot{\text { Ö}}_{4}$ : Bilim, sosyal medya, popüler kültür, modaya uyma çabası, çağı yakalama amacı, bunlardan en etkili olanlar popüler kültür ve çă̆ı yakalamaktır.

Ös: Bence bu kültür alışverişi bu büyük bir etken onun dışında ülkemizde bir ticaret yapıyorlar dış ilişkiler bunlar etkiliyor bence. Veya ülkemize gelip yerleşip burada iş yapan şirketler bunlar çok fazla etkiliyor. Sosyal medyada başlarda sayllabilir. Çünkü sosyal medyada çok fazla yabancı kelime kullaniyoruz.

Markalar, turizm ve okunan kitapların alıntı sözcüklerin Türkçeye girmesinde etkili olduğu görüşünde olan Türkçe öğretmeni adayının görüşü şu şekildedir:

Ö6: Başta bir sosyal medyanın burada çok etkili olduğunu düşünüyorum. İzlenilen filmler daha çok çeviri olduğu için oradaki kelimeleri de kullanabiliyorlar, giyim markaları, yenen yemeklerin farklı isimleri dahası hayranlık Batı hayranlığı, bir de Türkiye'den oraya göçler de oluyor. Oraya eğitim görmeye giden gençler oluyor, turizm ile gidenler de oraya gittiklerinde bir hayranlık uyanıyor ve bu kelimeleri kullanıyorlar. Okunan kitapların da etkili olduğunu düşünüyorum. Konular değişti. Özellikle günümüz romanlarında bir gencin Amerika'ya gitmesi Amerika'daki bir yaşamın ele alınması da yine etkili oluyor.

\subsection{Türkçe öğretmeni adaylarının yabancı dilde yayın yapan yayın organlarının Türkçeye yeni alıntı sözcükler girmesindeki etkisi hakkındaki görüşlerine dair bulgular}

Tamamen veya kısmen yabancı dilde yayın yapan yayın organlarının Türkçe üzerindeki etkisi ve bunların Türkçeye yeni alıntı sözcükler girmesindeki rolü hakkında Türkçe öğretmeni adaylarının görüşleri bu bölümde incelenmiştir. 
Tablo 14: Türkçe öğretmeni adaylarının yabancı dilde yayın yapan yayın organlarının Türkçeye yeni alıntı sözcükler girmesindeki etkisi hakkındaki görüşleri

\begin{tabular}{ll}
\hline $\begin{array}{l}\text { Yabancı dilde yayın yapan yayın organlarının Türkçeye yeni alıntı sözcükler } \\
\text { girmesindeki etkisi }\end{array}$ & $\mathbf{f}$ \\
\hline Müzik vasıtasıyla yeni sözcükler alma $\ddot{O}_{1}, \ddot{O}_{6}, \ddot{O}_{8}$ & 3 \\
\hline Popüler kültürün etkisi $\ddot{O}_{2}, \ddot{O}_{4}$ & 2 \\
\hline Günlük konuşma dilini etkileme $\ddot{O}_{3}$ & 1 \\
\hline Sunucuların etkisi $\ddot{O}_{5}$ & 1 \\
\hline Söz dizimini etkileme $\ddot{O}_{7}$ & 1 \\
\hline
\end{tabular}

Tablo 14 incelendiğinde Türkçe öğretmeni adaylarının 8’inin de görüş belirttiği görülmektedir. Bu tarz yayın yapan yayın organlarının müzik yoluyla yeni sözcükleri Türkçeye kattığı hakkında 3, popüler kültürün etkisini artırdığı yönünde 2, günlük konuşma dilini etkileme, sunucuların olumsuz tutumları ve söz diziminin bozulacağı hakkında da birer Türkçe öğretmeni adayı görüş belirtmiştir.

Yabancı dilde yapılan müzik yayınları aracılı̆̆ıyla Türkçeye yeni sözcükler girdiğini belirten Türkçe öğretmeni adaylarının görüşleri şu şekildedir:

Ö.: Aslında yani bozacağını da düşünmüyorum. Zaten kimse anlamıyor. "Gangam Style" vardı; bir ara çok meşhurdu. Belki artık güzel giyimli birine "Gangam Style" giymiș denilebilir. Moda olan şarkılara bazen kendimizi çok kaptırıyoruz. İşte bir araların apaçi dansı ona karşılık kolbastı çıkmıştı.

Ö6: Onların da etkisinin fazla olduğunu düşünüyorum. Çünkü özellikle müzik konusunda ülkemizde yabancı müzik dinleme oranı yüksek. Anlamadıkları hâlde de bunu sadece ben yabancı müzik dinliyorum izlenimi bırakmak için de dinleniyor. Bu tür yayın organları da bu tür davranışların yaygınlaşmasında etili oluyor. Bence bu yayınlar sınırlandırılmalı.

Ös: Yani bunun müzikle alakalı olduğunu düşünüyorum. Yabancı müziklere çok fazla yer verilmesini doğru bulmuyorum. Bunlara bir sınırlama getirilmelidir. Mesela şarkıda geçen somut bir kavram için kelime görselle de desteklenince o kavram için artık o kelime kullanılmaya başlanıyor.

Popüler kültürün etkisi hakkında görüş bildirenler ise şunları kaydetmiştir:

$\ddot{O}_{2}$ : İnternet ağının gelişmesiyle artık kendi topraklarımız üzerinde değiliz. Bütün dünya iletişim hâlinde. Bir siteye bir şarkı ekleyerek bunun milyarlarca insan tarafindan izlenmesi sağlanabiliyor. Bunun önüne geçmek tabi ki de imkânsız. Bu konuda yapılan transferleri tasvip etmiyorum. Ama bu da popüler kültürün getirdiği bir şey ve bunun önüne geçmek de günümüz dünyasında gerçekten zor.

$\ddot{O}_{4}$ : Türkiye'de yabancı yayın yapanlar popüler kültürün etkisi bence. İnsanların onların gençleri ne dinliyor ben de onları dinleyeyim. Ya da işte onlar nasıl şarkı söylüyor ben de öyle söyleyeyim. Mesela şey şarkı kültürümüzde ee onlar gibi söylemeye başlamışız artık. Sanatçllarımız Türkçe söylüyor olabilirler ama aksan yapıyorlar. Bunlar için Türkçe kelimelerin kullanımı teşvik edilebilir, hani söyleyiş tarzı, eski makamla söyleme tarzı gibi. Mesela moda programında "retro" kelimesini kullanıyorlar. Bu da modayla ilgilenen herkesin dikkatini çekiyor ve herkes kullanmaya başliyor bunun yerine daha eski tarzda denmesi daha başarılı olacaktır.

Bu tarz yayınların Türkçe söz dizimi üzerinde olumsuzluk yaratacağı hakkında görüş bildiren Türkçe öğretmeni adayı şunları iletmiştir:

$\ddot{O}_{7}$ : Yabancı dilde yayın yapan bir radyo hani o müziği seven insanlar var keyif aldığı için o müziği dinleyen insanlar var fakat hani nasıl desem geçerken o müzikle karşılaşmış olanlar var. İnsanlar anlamadıkları için çok fazla kelime boyutunda etkileyeceğini düşünmüyorum. Fakat söz dizimi yapımızda ufak tefek de olsa değişikliklerin olacağını düşünüyorum. 


\subsection{Türkçe öğretmeni adaylarının bir sözcük için alıntılama yapılacaksa bunun hangi dillerden olması gerektiği hakkındaki görüşlerine dair bulgular}

Dilde karşılanması gereken yeni bir kavram için alıntı bir sözcük alınacaksa bunun hangi dilden olması gerektiği hakkında Türkçe öğretmeni adaylarının görüşlerine bu bölümde yer verilmiştir.

Tablo 15: Türkçe öğretmeni adaylarının bir sözcük için alıntılama yapılacaksa bunun hangi dillerden olması gerektiği hakkındaki görüşleri

\begin{tabular}{ll}
\hline Bir sözcük için alıntılama yapılacaksa bunun hangi dillerden olması gerektiği & f \\
\hline Anadolu ağıları $\ddot{O}_{1}, \ddot{O}_{2}, \ddot{O ̈}_{8}$ & 3 \\
\hline Türk şiveleri $\ddot{O}_{1}, \ddot{O}_{2}, \ddot{O ̈}_{8}$ & 3 \\
\hline Ural - Altay dil grubu $\ddot{O}_{3}, \ddot{O}_{6}$ & 2 \\
\hline İngilizce $\ddot{O}_{4}, \ddot{O}_{5}, \ddot{O}_{6}, \ddot{O}_{7}$ & 4 \\
\hline Rusça $\ddot{O}_{4}$ & 1 \\
\hline Japonca $\ddot{O}_{4}$ & 1 \\
\hline Arapça $\ddot{O}_{5}, \ddot{O}_{6}$ & 2 \\
\hline Farsça Ö & 1 \\
\hline Latince $\ddot{O}_{5}, \ddot{O}_{6}$ & 2 \\
\hline Fransızca $\ddot{O}_{7}$ & 1 \\
\hline İtalyanca $\ddot{O}_{7}$ & 1 \\
\hline Moğolca Ö 6 & 1 \\
\hline
\end{tabular}

Tablo 15 incelendiğinde Türkçe öğretmeni adaylarının 8'inin de görüş belirttiği görülmektedir. Türkçe öğretmeni adaylarının Türkçenin kendi imkânları ile bu sözcüklere karşılık bulması gerektiği, ağızlara yönelmek, Türk şivelerinden alıntı yapılması ve Ural - Altay dil grubundan sözcük alınması gerektiği görüşüne daha fazla sahip oldukları görülmektedir. Türkçe öğretmeni adaylarının dikkat ettikleri bir diğer nokta ise ilişki içerisinde bulunulan üst kültürlerden sözcük alınması gerektiği yönündedir.

Anadolu ağızları ve Türk şivelerinden sözcük alınması gerektiği yönünde görüş bildiren Türkçe öğretmeni adayları şunları belirtmişlerdir:

Ö.: Anadolu ağızlarından yabancı dillerdense Anadolu ağızlarına bakmalıyız bence. Yoksa diğer Türk lehçeleri olabilir, Azerbaycan olabilir, Kazakistan, Türkmenistan olabilir. Çünkü onlar gerçekten Türkçe, saf Türkçe, eğer bunlarda yoksa eski eserlerden olabilir. Mesela Orhun Abideleri olabilir. Hiçbir şekilde yabancı dile gitmememiz gerektiği görüşündeyim.

$\ddot{O}_{2}$ : En güzel örneğini bize çok güzel anlatan Mustafa Kemal ATATÜRK’tür. Onu saygıyla anıyorum. Çünkü kendisi bu tip zor durumlarda kaldığında . Türkçenin diğer kollarından faydalanmıştır. Anadolu sahasındaki bazı kelimeleri kullanmıştır. Özellikle ağızları kullanmıştır. Bunun için çok geniş bir yapıya sahibiz çünkü tarih boyunca geniş coğrafyalarda bulunmuşuz. Orta Asya'da zaten çok değişik Türk lehçeleri var. Oralardan bulabileceğimizi düşünüyorum. Yabancı dillere de açıkçası pek ihtiyacımız olduğunu düşünmüyorum.

Ural - Altay dil grubundan sözcük alınması gerektiğini düşünenlerden birinin görüşleri ise şu şekildedir:

$\ddot{O}_{3}$ : Türkçenin söz dizimine daha yakın dillerden alınması gerekir. Yoksa ilk çıktı̆̆ında nerede çıkmışsa o dilden almak gerekir. Moğolca gibi dillerden almalıyız. Japoncadan, Koreceden almalıyız. Hatta söz dizimi benzer yakın olan üst kültürden sözcük almalıyız. 
Arapça, Farsça, Latince, İngilizce, Fransızca, İtalyanca ve Moğolcadan sözcük alınması gerektiği yönünde görüş bildirenler ise şunları kaydetmişlerdir:

$\ddot{O}_{5}: \mathrm{O}$ da konuya göre değişebilir. Dinî bir konuysa Arapçadan alıntı yapılabilir. Tip ile ilgiliyse Latinceden alıntı yapılabilir. Ya da İngilizceden de çok rahat alıntı yapılabilir. Mesela teşekkür ederim yerine bazen mersi diyorlar. Bu da Fransizcadır.

Ö6: Kategoriye göre değerlendirmek lazım. İlişkili olduğumuz ülkelere göre de değerlendiririm. Kategori derken hani dinî, siyasi en çok o dile yatkın kelimeleri almamız lazım ve komşuluk ilişkilerinin de bunda önemli olduğunu düşünüyorum. Siyasi ilişkilerimizin de bunda önemli bir faktör olduğunu düşünüyorum. Ural Altay dil grubundan alınabilir. Ses özelliklerinin uygunluğuna dikkat etmeliyiz. Sıralama yapacak olursak bir numaraya Arapça ve Farsça, İngilizce, Latince, Moğolca olabilir.

$\ddot{O}_{7}:$ Şu an Batı ile yüzümüz Batıya dönük olduğu için bu Batıdan bir dil olması lazım bence İngilizceden alınsa daha iyi olur. Farklı bir ülkeye gittiğimizde o kelimeyi söylediğimizde bizi anlayabilirler. Daha sonra Fransizcan alabiliriz, İtalyancadan alabiliriz.

\subsection{Türkçe öğretmeni adaylarının menülerde yer alan yabancı sözcükler hakkındaki görüşlerine dair bulgular}

Türkçe öğretmeni adaylarının lokanta, restoran, kafe $v b$. yerlerdeki menülerde yer alan yabancı sözcükler hakkındaki görüşleri Tablo 16'da belirtilmiştir:

Tablo 16: Türkçe öğretmeni adaylarının menülerde yer alan yabancı sözcükler hakkındaki görüşleri

\begin{tabular}{ll}
\hline Menülerde yer alan yabancı sözcükler & $\mathrm{f}$ \\
\hline Türkçe karşılıklarına da yer verme $\ddot{\mathrm{O}}_{1}, \ddot{\mathrm{O}}_{4}, \ddot{\mathrm{O}}_{5}$ & 3 \\
\hline Genel kültüre katkıda bulunma $\ddot{\mathrm{O}}_{2}$ & 1 \\
\hline En gereksiz kullanım alanı olma $\ddot{O}_{3}$ & 1 \\
\hline Farklılık oluşturma çabası Ö & 1 \\
\hline Zamanla Türkçede yer alma $\ddot{O}_{7}, \ddot{O}_{8}$ & 1 \\
\hline
\end{tabular}

Tablo 16 incelendiğinde Türkçe öğretmeni adaylarının 8’inin de görüş belirttiği görülmektedir. Türkçe öğretmeni adaylarından bu sözcükler için Türkçe karşllıklarına da yer verilmesi gerektiği yönünde 3, bu sözcüklerin zamanla Türkçede yer almaya başlayacağı üzerine 2, genel kültürü artırdığı hakkında, farklılık oluşturma çabası için bu kullanımların olduğu hakkında ve gereksiz kullanım alanı olduğu hakkında birer öğretmen adayı görüş bildirmişlerdir. Türkçe öğretmeni adaylarının bu kullanımları olumlu karşılamadıkları ve telaffuz edemedikleri bu isimlerdeki ürünleri tercih ederken zorlandıkları görüşlerinden hareketle belirlenmiştir.

Yabancı sözcüklerle menü oluşturulduğunda Türkçe karşılıklarının da verilmesi gerektiği hakkında görüş bildirenler şunları kaydetmişlerdir:

Öı: Bunların da Türkçeleri yazılması gerekiyor. Ya da Türkçe karşılıkları. Şimdi lokanta isimleri bile yabancılaşmaya başladı. Farklı tamlamalar girmeye başladı. Ama mesela sandviç yerine ekmek arası desek böyle bir denetim oluşturulacaksa üniversitelere görev düşer mi bilmiyorum ama bu görev bence Milli Eğitim'e düşer.

Ö$_{4}$ : Özellikle makarnalarda oluyor İtalyanca isimler. Kafelerde İngilizce isimler oluyor. Mesela ona salçalı makarna yazsa bence daha başarılı olur. İlle de yabancı dilde yazacaklarsa altına Türkçe karşılığını da yazmalılar. Ĕ̆er adını söyleyemiyorsam garsona resmini göstererek bundan istiyorum derim. Adını söylememeyi tercih ederim. Çünkü telaffuz edemiyorum.

$\ddot{O}_{5}$ : Bu yabancı isimlerin insanları kandırdığını düşünüyorum. Yani yemek neyse onun ismi yazılmalı Türkçe olarak. Bilmiyorum ben hani bir dilde olan kelimeyi anlamıyorum ne yiyeceğimi de bilemem 
tabi ki de Türkçesi yazılsın. Adını söyleyemediğim bir ürün olursa bunun adını söylemekten çekiniyorum ve onu yiyip içmekten vazgeçiyorum ve başka bir şey yerim. Bazen de resmini göstererek istediğim oluyor.

Bu tarz kullanımların kişinin genel kültürünü artırdığı yönünde görüş belirten Türkçe öğretmeni adayının fikirleri ise şöyledir:

\begin{abstract}
$\ddot{O}_{2}$ : Şimdi şöyle bir şey var oralarda yiyeceğiniz bir yemek herhangi bir ülkenin kültürüne aitse bunun ismini değiştirmek ne kadar doğru. Örneğin Meksika mutfağına has bir şey yediğiniz zaman bu sizin kültürünüzü geliştiren entelektüellik kazandıran bir şey. Ama fakat çay yerine "tea" yazıyorsa İngilizcesi yazıyorsa limonata yerine İngilizcesi yazıyorsa bunlar tabi ki de tasvip edilecek durumlar değil. Fakat bir yöreye ait yemek ve içecekse onu Türkçeleştirmeyi de pek doğru bulmuyorum açıkçası. Genellikle bunları sipariş verirken söylerim herhangi bir utangaçlık yaşamam, hiç olmadı menüyü tutup şunu istiyorum derim yani.
\end{abstract}

$\mathrm{Bu}$ sözcüklerin zamanla Türkçe içerisinde yer alacağı ve gelecek nesiller arasında kullanımının yaygınlaşacağı ve bunlar için önlem alınması gerektiğini düşünen Türkçe öğretmeni adaylarının görüşleri ise şu şekildedir:

\begin{abstract}
$\ddot{O}_{7}$ : Bizim Türk mutfağımız zengin bir mutfak. Türkçe yemek isimlerimiz varken yabancıları neden tercih ediliyor ki bence tamamen kaldırılmalı. Tamamen Türkçe yemek isimleri olmalı. Ben zaten bu yabancı yemek isimlerinin de özenti olduğunu düşünüyorum. Hani öyle bir Batı hayranlığı olarak düşünüyorum. Türkçe isimler kullanalım bence. Ben mesela köftenin mantının Türkçe olduğunu sanıyordum eskiden daha çok özen gösterilebilir. Gençler arasında bu yayılma olacak şimdiki yemeklerimiz nasılsa yabancı kökenliyse ilerideki isimlerimizde yabancı kökenli olacaktır. İnsanlar yavaş yavaş alışıyorlar belki de alışmak istiyorlar. Kulağa hoş gelen kelimeler oldukları için kullanılıyorlar. Bazıları özenti dolayısıyla kullanılıyorlar.
\end{abstract}

Ös: Ya mesela ne yediğimizi bilmiyoruz yani. Menülerde özellikle çok farklı isimler var. İçeriğini bilmiyoruz. İsmini bilmediğim şeylerin genelde ne olduğunu garsona sorarım. Bu kelimeler çok sik kullanıldığı için zihinlerde sürekli yer ettiği için menüler Türkçeye yeni kelimelerin girmesinde etkili oluyor. Bir yerden sonra kabul görüyorlar.

\title{
3.15. Türkçe öğretmeni adaylarının yabancı dilde eğitimin Türkçeye yeni sözcüklerin girmesi üzerindeki etkisi hakkındaki görüşlerine dair bulgular
}

Yabancı dilde eğitimin Türkçeye alıntı sözcüklerin girmesindeki rolü hakkında Türkçe öğretmeni adaylarının görüşlerine bu bölümde yer verilmiştir.

Tablo 17: Türkçe öğretmeni adaylarının yabancı dilde eğitimin Türkçeye yeni sözcüklerin girmesi üzerindeki etkisi hakkındaki görüşleri

\begin{tabular}{ll}
\hline Yabancı dilde eğitimin etkisi & $\mathrm{f}$ \\
\hline Yabancı dilde eğitimin erken başlaması $\ddot{\mathrm{O}}_{1}$ & 1 \\
\hline Önce Türkçeyi öğretme $\ddot{\mathrm{O}}_{1}, \ddot{\mathrm{O}}_{2}, \ddot{\mathrm{O}}_{4}, \ddot{\mathrm{O}}_{6}, \ddot{\mathrm{O}}_{7}, \ddot{\mathrm{O}}_{8}$ & 6 \\
\hline Gerekli alanlarda yer verme $\ddot{\mathrm{O}}_{3}, \ddot{\mathrm{O}}_{4}$ & 2 \\
\hline Sinırlandırma $\ddot{\mathrm{O}}_{5}, \ddot{\mathrm{O}}_{6}$ & 2 \\
\hline
\end{tabular}

Tablo 17 incelendiğinde Türkçe öğretmeni adaylarının 8’inin de görüş belirttiği görülmektedir. Türkçe öğretmeni adaylarının görüşlerinin yabancı dilde eğitim verilmeden önce öncelikle Türkçenin iyi bir şekilde öğretilmesi gerektiği, bu tarz eğitimlerin tıp gibi gerekli alanlar dışında sınırlandırılması gerektiği ve yabancı dil ile eğitime çok erken başlanmaması gerektiği yönünde birleştiği görülmektedir.

Yabancı dilde eğitime başlanmadan önce öğrencilerin iyi bir Türkçe bilgisini elde etmeleri gerektiğini düşünenlerin görüşleri şu şekildedir: 
Ö.: Şimdi çok erken başladılar yabancı dil eğitimi vermeye. Birinci, ikinci sınıfta işte renkler haftalar günler cümle kurmayı öğretiyorlar. Çok ağır çok zor bence dil açısından da yapmamaları gerekir. Onun yerine Türkçeyi daha iyi öğretmeleri lazım bence. Bu kadar fazla dil eğitimine yer vermek illa ki bir yerde dilimizi bozacaktır. İlkokullarda erken yaşta bence yabancı dil eğitimine başlanmamalı bence.

Ö6: Oralardan mezun olan kişilerin yabancı kelimeleri günlük hayatlarına yerleştirdiklerine inanıyorum. Bu yüzden bunun da bir sınırlaması olması gerektiğini düşünüyorum. Yabancı dil ana dili yerine geçecek şekilde bir eğitim dili olarak verilmemeli. Ana dil iyi bilinmeden yabancı dile geçildiği zaman bu tarz yerlerden mezun olan insanlar genellikle makam mevki sahibi, ekranlarda boy gösteren kişiler oldukları için Türkçemize yeni kelimelerin girmesinde etkili olduklarını düşünüyorum.

Özellikle lisans düzeyinde sürekli gelişim gösteren alanlarda dünya ile aynı hızı yakalayabilmek adına yabancı dilde eğitim verilmesi gerektiğini düşünenler görüşlerini şöyle bildirmiştir:

$\ddot{O}_{3}$ : Aslında hocam hani mesela dil eğitimi alanlarda Almanca, İngilizce falan veya hani 4 yl İngilizce tıplar var 6 yl daha doğrusu hani İngilizce veya Almanca yabancı dil gerekliyse o dilde verilmeli o eğitim. İllaki kullanma oluyordur. Çevrelerinde kullanırlar ve bu yayllı. Ama bu tarz bölümlerde gerekliyse eğitim yabancı dilde verilmelidir.

$\ddot{O}_{4}$ : Sürekli gelişim göstermesi gereken alanlarda tüm dünyada aynı olan bilimlerde burada ilerleyen kişiler başka bir ülkede de çalışabilir. O dile ihtiyaç olabilir. O yüzden gerekli alanlarda devam etmelidir. Belli başlı yerlerde eğitim devam etmeli ve denetlenmeli çünkü yabancı dilde öğrenim veren okullar mantar gibi çoğaldılar.

$\mathrm{Bu}$ tarz eğitimlere bir sınırlandırma getirilmesi gerektiği görüşünde olan Türkçe öğretmeni adaylarından biri görüşünü şu şekilde kaydetmiştir:

Ö. Mesela Amerikan kolejlerini falan biliyorum. Onlar da Amerikan İngilizcesi ve kültürünün verilmesine yönelik eğitim veriyorlar. Amerikan İngilizcesi ve kültürünü yayma amaçlı olduğunu düşünüyorum. Dil aynı zamanda kültür de yayar. Hani kültür yayma amaçlı daha çok bunlar. Ben pek desteklemiyorum. Bu tarz eğitimlerin sınırlandırılması gerektiği görüşündeyim.

\subsection{Türkçe öğretmeni adaylarının çevirilerin Türkçeye yeni sözcüklerin girmesi üzerindeki etkisi hakkındaki görüşlerine dair bulgular}

Çeviri eserlerde yer alan yabancı sözcükler ve çevirilerin Türkçeye yeni alıntı sözcükler girmesi üzerindeki etkisi hakkında Türkçe öğretmeni adaylarının belirttiği görüşlere bu bölümde yer verilmiştir.

Tablo 18: Türkçe öğretmeni adaylarının çevirilerin Türkçeye yeni sözcüklerin girmesi üzerindeki etkisi hakkındaki görüşleri

\begin{tabular}{ll}
\hline Çevirilerin etkisi & $\mathrm{f}$ \\
\hline Edebî nitelikte olmama $\ddot{O}_{1}$ & 1 \\
\hline Kontrol $\ddot{O}_{1}, \ddot{\mathrm{O}}_{2}, \ddot{\mathrm{O}}_{4}, \ddot{\mathrm{O}}_{6}$ & 4 \\
\hline Yabancı sözcük kullanma $\ddot{\mathrm{O}}_{3}, \ddot{\mathrm{O}}_{5}, \ddot{\mathrm{O}}_{8}$ & 3 \\
\hline Sinırlama Ö & 1 \\
\hline
\end{tabular}

Tablo 18 incelendiğinde Türkçe öğretmeni adaylarının 8’inin de görüş belirttiği görülmektedir. Türkçe öğretmeni adaylarının anlık çevirilerde kullanılan yabancı sözcüklerin Türkçeye yeni sözcükler girmesinde etkisi olmayacağını düşündükleri, ancak yazılı çevirilerde ise Türkçenin bundan çok fazla etkilendiği, herkesin çevirmen olmaması gerektiği, kontrol mekanizmaları kurulması gerektiği, çeviri bir eserde kullanılabilecek yabancı kelime sayısının sınırının belirlenmesi gerektiğine dair görüş bildirdikleri görülmektedir. 
Çeviriler aracılığıyla yeni sözcüklerin Türkçeye girmesinin engellenmesi için kontrol mekanizması geliştirilmesi gerektiğini belirtenlerden bazılarının görüşleri şöyledir:

$\ddot{O}_{2}$ : Gerçekten çok etkili olduğunu düşünüyorum. Çünkü bazı çevirmenler bu işi bilmeden yapıyorlar. Mesela Yüzüklerin Efendisi kitabının çevirisini yapan kişi. Kitabın dili gerçekten ağırdır. Bu dildeki bazı kelimeleri kendi anlamılla o kadar güzel entegre etmiş ki o kadar güzel isimler uydurmuş ki hani çevirmen gerçekten kitabı etkiliyor. Midilli hanı, ayrık vadi vs. kötü bir çevirmen insanı gerçekten kitaptan soğutabilir. Çevirmenlerin bu konuda çok çok etkili olduğunu düşünüyorum. Yayınevleri çevirmenlerin gerçek bir eğitimden geçmesini sağlaması ve staj alanlarını takip etmesi gerekiyor. Çevirmenlerin yeterliklerinin ölçülebilir bazı değerlendirmeler yapılması lazım. Her önüne gelen de çevirmen olmamalı.

$\ddot{O}_{4}$ : Ceviri yapan insanların her seyden önce çok güzel Türkçe bilmeleri gerekiyor ve oradaki karșlığı yerine hani anlık çeviride oradaki kelimeyi kullanıyor olabilir ama Türkçesini kullanmalı. Türkçe seviyesi yüksek olmalı. Romanlardaki çeviriler ise çeviriyi yapan kişinin yapısıyla alakalı. Kendi kafasında herkes bunu anlıyor diye düşünüyor. Yayınevlerine büyük rol düşüyor. Bir kere kontrol ediyorlarsa iki kere kontrol etmeliler. Bunun için görevlendirilmiş elemanları olmalı. Bunun için Türkçe öğretmenliği mezunu kişilere başvurmalılar.

Kullanılan yabancı kelimelerin zamanla anlamdan hareketle insanların zihninde yer ettiği ve kullanılmaya başlandığını belirten Türkçe öğretmeni adaylarının görüşleri şu şekildedir:

$\ddot{O}_{3}$ : Türkçeye çevrilen romandaki Fransızca olan bir kelime konmuşsa biz anlamdan o kelimenin anlamını çıkarıyoruz ve kullanmaya başlıyoruz ve hayatımıza bu kelime girmiş oluyor.

Ö$_{5}$ : Yabancı bir kelimeyi yabancı başka bir kelimeyle Türkçeye aktarmaya çalıștıkları için Türkçe bu durumdan çok fazla etkileniyor. Bu tabi ki bize Türkçe karşlığını veremez. Türkçesi varken Türkçe aktarım sağlanmalı. Bu tarz durumların Türkçeyi bozduğunu düşünüyorum.

Çeviri bir eserde bulunması gereken yabancı sözcük sayısı için sınırlandırma getirilmesi gerektiği görüşünde olan Türkçe öğretmeni adayı şunları ifade etmiştir:

$\ddot{O}_{7}$ : Anında çevirilerin fazla etki yapacağını düşünmüyorum. Tercümanın söylediğini o anlık alıyoruz ama daha sonra kullanmiyoruz. Ama diğer mesela roman olsun hikâye olsun bu tür metinlerde yapılan çevirilerde alabiliriz yabancı kelimeleri bunlar etkili olabilir bu yüzden çevirmenlerin dikkat etmesi gerekir. Bir sınırlama getirilmeli yapılacak eserden fazla yabancı kelime sokulmamalı bir sınır koyulmall.

\section{Sonuc}

Dildeki çeşitliliği artırıp dilin devamlılı̆̆ının sağlanması, canlılığının korunması gibi özellikler taşıyan alıntı sözcükler hakkında Türkçe öğretmeni adaylarının görüşlerinin belirlenmesine yönelik gerçekleştirilen bu çalışmada Türkçe öğretmeni adaylarının alıntı sözcükleri belirlerken bazı kurallardan hareket ettikleri, alıntı sözcüklerin Türkçede bulunmasını normal karşıladıkları, bunu dilin olması gereken bir süreci olarak gördükleri tespit edilmiştir. Ancak Türkçe öğretmeni adaylarının bu sözcüklerin fazla kullanımını hoş karşılamadıkları, gerek özenti gerek teknoloji gerekse kitle iletişim araçlarının yabancı sözcüklerin sıklıkla kullanılmasına sebep olmasını hoş karşılamadıkları ve bunun Türkçede yozlaşmaya sebep olacağını öngördükleri ve alıntı sözcük almak yerine ilk önce Türkçenin tarihî ve çağdaş kaynaklarına başvurmak gerektiği yönünde temel görüşlere sahip oldukları sonuçlarına ulaşılmıştır. Ulaşılan sonuçları şöyle dikkatlere sunmak mümkündür:

a. Türkçe öğretmeni adayları ile yapılan görüşmeler sonucunda Türkçe öğretmeni adaylarının alıntı sözcüklerin Türkçenin ses özellikleri, alıntı sözcüklerin ses özellikleri, büyük ünlü uyumunu arama, aynı coğrafyayı paylaşma ve yazı dilindeki belirginlik sayesinde alıntı 
sözcükleri fark ettikleri tespit edilmiştir. Osam’a (1997) göre de Türkçedeki alıntı sözcüklerin fark edilmesinin ve belirlenmesinin yüksek orana sahip olduğu sonucuna ulaşılmıştır.

b. Alıntı sözcüklerin hangi dillerden geldiklerini belirleme yollarının ise popüler kültür, televizyon ve sinema, alıntı sözcüklerin fazla olduğu diller, eğitim dili, dinî terimler, bilinen yabancı diller, sosyal medya, alınan eğitim ve sözlük kullanma olduğu tespit edilmiştir. Türkçe öğretmeni adayları özellikle dinî etkenlerden dolayı Arapça ve Farsçadan gelen sözcükleri belirlerken daha rahat olduklarını ifade etmişlerdir.

c. Alıntı sözcükler yerine Türkçe eş anlamlılarının kullanımı hakkında ise Türkçe öğretmeni adaylarının dikkat etme, Türkçeleşmiş olanları ayırt etmeden kullanma, yeni alıntı sözcükleri bilinçli olarak kullanmama, Türkçe ses yapısına uyumu ve resmî yazılarda önem verme görüşlerine sahip oldukları tespit edilmiştir. Osam'a (1997) göre de yine yazıda yabancı sözcük kullanımına karşı yüksek bir direnç olduğu sonucu ortaya çlkmıştır.

d. Alıntı sözcüklerin geldikleri dildeki gibi kullanımları hakkında Türkçe öğretmeni adaylarının sözcükleri alındıkları dildeki gibi kullanılma, ek getirme, Türkçe karşılık bulma, söylenişlerini / yazılışlarını Türkçeleştirme ve Türk Dil Kurumunu takip etme eğiliminde oldukları sonucuna ulaşılmıştır.

e. Alıntı sözcüklerin yazımının karıştırılmasının önüne geçmek için yapılacaklar hakkında sosyal medya kullanma, kurslar gerçekleştirme, hizmet içi eğitim verme ve metin kullanma görüşleri tespit edilmiştir. Yazımı karıştııılan sözcüklerin aralarındaki fark hakkında öğretici çalışmalar yapma konusunda genellikle Türkçe söz konusu olduğunda eleştirilen sosyal medyanın araç olarak kullanılıp bu yanlışlıkların önüne geçme çalışmaları yapılması gerektiğini belirten görüş oldukça dikkat çekicidir.

f. Alıntı sözcüklerin söylenişinde yaşanan zorlukların önüne geçmek için neler yapılacağı hakkında kitap okuma, yazım kılavuzu kullanma, Türkçe karşılık bulma, telaffuz çalışmaları yapma, konferans gerçekleştirme ve kamu spotu hazırlama görüşlerine ulaşılmıştır.

g. Alıntı veya yabancı sözcüklerin konuşmalarda sıklıkla kullanılması ile ilgili olarak: dili yozlaştırma, samimiyetsizlik, uyarma, denetim, bilinçlenme, özenti ve ilgi çekicilik görüşleri elde edilmiştir. Türkçe öğretmeni adaylarının özellikle Türkçenin yozlaşmasının önüne geçmek için önemli çalışmalar yapılması gerektiği hakkında bilinçli oldukları görülmüştür.

h. Alıntı sözcüklerin ağırlıklı olarak kullanıldıkları metinleri anlamada yaşanan zorluklarla ilgili olarak Türkçe öğretmeni adayları roman ve hikâyelerin anlaşılmaması, şiirleri anlamada zorluk çekme, sağllkla ilgili metinler, bilimsel metinlerde zorluk çekme, dipnot verme ve makale ve köşe yazılarında zorluk çekme konularında sıkıntı yaşadıklarına dair görüşleri tespit edilmiştir.

i. Türkçe öğretmeni adaylarının anlamını bilmedikleri alıntı sözcüklerin anlamını araştırmak için başvurdukları kaynaklar hakkındaki görüşleri şunlardır: Google Translate, TDK internet sayfası, internet, Türkçe Sözlük ve uzman birisine danışma.

j. Türkçe öğretmeni adaylarının Türkçesi varken yeni bir alıntı sözcüğün Türkçede yer alması hakkında entelektüel görünme kaygısı, özenti, Türkçeye giriş yollarının tespiti ve dil bilinci ile hareket etme görüşlerine sahip oldukları sonucuna ulaşılmıştır.

k. Türkçe öğretmeni adaylarının alıntı sözcüklerin Türkçeye girmesinde etkili olan yollar hakkında sosyal medya, arkadaşlarla kurulan iletişim, sinema, markalar, modaya uyma çabası, Türk Dil Kurumunun çalışmalarının yetersizliği, televizyon, bilim, popüler kültür, din, turizm, okunan kitaplar ve ticaretin etkili olduğu görüşüne sahip oldukları tespit edilmiştir.

1. Türkçe öğretmeni adaylarının yabancı dilde yayın yapan yayın organlarının Türkçeye yeni alıntı sözcükler girmesindeki etkisi hakkında müzik vasitasıyla yeni sözcükler alma, popüler kültürün 
etkisi, günlük konuşma dilini etkileme, sunucuların etkisi ve söz dizimini etkileme görüşlerine sahip oldukları sonucuna ulaşılmıştır.

m. Türkçe öğretmeni adaylarının bir sözcük için alıntılama yapılacaksa bunun hangi dillerden olması gerektiği hakkında Anadolu Ağızları, Türk Şiveleri, Ural - Altay Dil Grubu, İngilizce, Rusça, Japonca, Arapça, Farsça, Latince, Fransızca, İtalyanca ve Moğolcadan alıntı sözcük alınması gerektiği görüşüne sahip oldukları belirlenmiştir. Osam’a (1997) göre de yabancı kökenli sözcüklerin alınmasına karşı olunduğu sonucu ortaya çlkmıştır.

n. Türkçe öğretmeni adaylarının menülerde yer alan yabancı sözcükler hakkında Türkçe karşılıklarına da yer verme, genel kültüre katkıda bulunma, en gereksiz kullanım alanı olma, farklılık oluşturma çabası ve zamanla Türkçede yer alma görüşlerine sahip oldukları sonucuna ulaşılmıştır.

o. Türkçe öğretmeni adaylarının yabancı dilde eğitimin Türkçeye yeni sözcüklerin girmesi üzerindeki etkisi hakkında yabancı dilde eğitimin erken başlaması, önce Türkçeyi öğretme, gerekli alanlarda yer verme ve sınırlandırma görüşlerine sahip oldukları tespit edilmiştir.

p. Türkçe öğretmeni adaylarının çevirilerin Türkçeye yeni sözcüklerin girmesi üzerindeki etkisi hakkında edebî nitelikte olmama, kontrol, yabancı sözcük kullanma ve sınırlama görüşlerine sahip oldukları sonucuna ulaşılmıştır.

\section{Kaynakça}

Akalın, H. Ş. (2014). Türkçede söz yapımı yolları ve sözlükselleşme. XI. Millî Türkoloji Kongresi Bildirileri 11-13 Kastm 2014, İstanbul, 831-841.

Aksan, D. (1972) Türk dili zengin bir dil midir? Türk Dili, XXVI/248, 119-124.

Aksan, D. (2004). Türkçenin sözvarhlğı. Ankara: Engin Yayınevi.

Aksan, D. (2015). Türkiye Türkçesinin dünü, bugünü, yarın. Ankara: Bilgi Yayınevi.

Alyılmaz, C. (1997). Teknoloji ve dil. Atatürk Üniversitesi Türkiyat Araştırmaları Enstitüsü Dergisi, 8, 33-36.

Alyılmaz, C. (2010). Türkçe öğretiminin sorunları. Turkish Studies, 5(3), 728-749.

Alyılmaz, S. (2005). Atatürk ve Türk dili. Manas Üniversitesi Sosyal Bilimler Dergisi, 13, 81-83.

Alyılmaz, S. (2013). Güncel Türkçe Sözlük’te yer alan argo nitelikli kavram işaretleri. Leyla Karahan Armağanı, 165-192. Ankara: Akçağ Yayıncılık.

Alylmaz, S. (2017). On Plurality Category and Teaching in Turkish. Journal of Education and Training Studies, 5(9), 94-99.

Alyılmaz, S. (2018). Türkçenin yabancı dil olarak öğretiminde hedef kitlenin / "öğrenen”in önemi. Uluslararası Türkçe Edebiyat Kültür Eğitim Dergisi, 7(4), 2452-2463.

Argunşah, M. (2010). Sözüm Türkçe üstüne. İstanbul: Kesit Yayınları.

Bayraktar, N. (2013). Ölmekte olan Türk dilleriyle ilgili alınabilecek önlemler üzerine. Dilleri ve Kültürleri Yok Olma Tehlikesine Maruz Türk Topluluklarl 4. Uluslararası Türkiyat Araştırmaları Sempozyumu, 23 -26 Mayıs 2012 Bildirileri. Ankara, 131-138

Bazin, L. (2010). Türk lengüistiği ve kültür alışverişi meseleleri. Türkçenin Derin Yapısı. Ankara: Belen Yayıncılık. 521-552. (çev. Efrasiyap Gemalmaz. Yayıma Hazırlayanlar: Cengiz Alyılmaz ve Osman Mert).

Biçer, N. (2017). Türkçe öğretimi tarihi. İstanbul: Kesit Yayınları.

Boz, E. (2011). Türkçe sözlüklerde batı kökenli çoklu yazımlı sözcükler. III. Uluslararası Dünya Dili Türkçe Sempozyumu 2010, İzmir, 223-237. 
Buran, A. (2008). Yabancı Diller Karşısında Türkçe. Makaleler. (ed. M. Dursun Erdem). Ankara: Turkish Studies Publication, 165-169.

Büyüköztürk, Ş., Çakmak, E. K., Akgün, Ö. E., Karadeniz, Ş. ve Demirel, F. (2009). Bilimsel araştırma yöntemleri. Ankara: Pegem Akademi.

Chomsky, N. (2001). Dil ve zihin. Ankara: Ayraç.

Creswell, J. (2013). Araştırma deseni (çev. Selçuk Beşir Demir.). Ankara: Eğiten Kitap.

Çoban, İ. (2018). Türkçe öğretmeni adaylarını Türkçedeki alıntı sözcükleri kullanma düzeylerinin incelenmesi. Yayımlanmamış Doktora Tezi, Erzurum: Eğitim Bilimleri Enstitüsü.

Çoban, İ. ve Alyılmaz, C. (2019). Türkçe öğretmeni adaylarının alıntı sözcükleri kullanma düzeyleri üzerine bir inceleme. Avrasya Uluslararası Araştırmalar Dergisi, 7(17), 163-198.

Çoban, İ. ve Polatcan, F. (2018). An analysis on views of prospective Turkish language teachers on peer assessment. European Journal of Education Studies, 4(4), 161-175.

Demirci, K. (2013). Ticari adlardaki kural dışı yazımlara bir yaklaşım. Önder Göçgün'e Armağan C 1. (ed. Mithat Aydın). Denizli: Pamukkale Üniversitesi Yayınları.

Eker, S. (2013). Modernleşme sürecinde Türkiye'de terimbilim çalışmalarına genel bir bakış. Altaistics and Turcology, 2013/1, 68-95

Ekiz, D. (2009). Bilimsel araştırma yöntemleri (Geliştirilmiş 2. Baskı), Ankara: Anı Yayıncılık.

Ersoylu, H. (2000). Çağdaş Türkiye Türkçesinin problemleri - 8: batı kaynaklı kelimelerin kullanımında alan genişlemesi. Türk Dili, 586, 331-345

Güllüdağ, N. (2012). Yazılı ve görsel basında dil estetiği. 21. Yüzyılda Eğitim ve Toplum, 1(1), 49-58.

Gülsevin, G. (2015). Dil kirliliği sorunu (Türkçede yabancı unsurlar sorunu). Türkçenin Çağdaş Sorunları. (ed. Gürer Gülsevin ve Erdoğan Boz). Ankara: Gazi Kitabevi, 135-164.

Hengirmen, M. (2011). Türkçenin özgürlük savaşı. 38. ICANAS Bildiriler Cilt II, Ankara, 749-758.

İmer, K., Kocaman, A. ve Özsoy, A. S. (2011). Dilbilim sözlüğü. İstanbul: Boğaziçi Üniversitesi Yayınevi.

Kara, M. (2007). Yabancılaşmanın yeni yüzü: defter kapakları (dil/görsellik). Turkish Studies, 2(2), 390-403.

Karaağaç, G. (2013). Dil bilimi terimleri sözlüğü. Ankara: Türk Dil Kurumu Yayınları.

Karaağaç, G. (2015). Türkçenin alıntılar sözlüğü. Ankara: Akçağ Yayıncılık.

Karaca, V. İ. (2011). Türkiye Türkçesinde alıntı sözcüklerde görülen ses olayları üzerine bir inceleme. Yayımlanmamış yüksek lisans tezi. Fırat Üniversitesi, Elazı̆̆.

Karadağ, Ö. (2013). Kelime öğretimi. İstanbul: Kriter Yayınevi.

Karakılıç Akı, S. (2007). Türkçenin güncel problemleri. Yayımlanmamış Yüksek Lisans Tezi. Ankara: Gazi Üniversitesi Sosyal Bilimler Enstitüsü.

Karpuz, H. Ö. (2015). Anadili bilinci sorunu. Türkçenin Çağdaş Sorunları. (ed. Gürer Gülsevin ve Erdoğan Boz). Ankara: Gazi Kitabevi, 205-223.

Korkmaz, Z. (1995). Batı kaynaklı yabancı kelimeler ve dilimiz üzerindeki etkileri. Türk Dili, 524, 843858.

Korkmaz, Z. (1995). Türk dilinin yabancı dillere karşı korunması için alınması gereken önlemler. Türk Dili, 528, 1268-1280.

Levend, A. S. (1957). Yabancı kelime salgını. Türk Dili, 65, 249-251.

Lüle Mert, E. (2012). Türkçe öğretmeni adaylarının yabancı kökenli sözcük kullanımlarına ilişkin bir inceleme. Turkish Studies, 7(4), 2357-2369.

Merriam, S. B. (2013). Nitel araştırma desen ve uygulama için bir rehber. Ankara: Nobel Yayınları. (çev. Selahattin Turan). 
Mert, O. (2009). Ötüken Uygur dönemi yazıtlarından tes - tariat - şine us. Ankara: Belen Yayıncılık. Muallimoğlu, N. (1999). Türkçe bilen aranıyor. İstanbul: Avcıl Basım Yayın.

Osam, N. (1997). The attitude of Turkish people towards the use of foreign words in a Turkish context. Yayımlanmamış doktora tezi. Hacettepe Üniversitesi, Ankara.

Özçelik, S. (2015). Türkçe ve bilim dili sorunu. Türkçenin Çağdaş Sorunları. (ed. Gürer Gülsevin ve Erdoğan Boz). Ankara: Gazi Kitabevi, 237-246.

Özkan, M. (2010). İnsan iletişim ve dil. İstanbul: Akademik Kitaplar.

Perry, J, R. (1985). Language reform in Turkey and Iran. International Journal of Middle East Studies, 17(3), 295-311.

Porzig, W. (1985). Dil denen mucize -I-. (çev. Vural Ülkü). Ankara: Kültür ve Turizm Bakanlığı Yayınları.

Sezgin, F. (2002). Türkçede batı kaynaklı kelimelerin yoğunluğu ve yabancılaşma sebepleri. Türkler, $C$. $18,80-101$.

Sis, N. (2015). Medya dili sorunu. Türkçenin Çağdaş Sorunları. (ed. Gürer Gülsevin ve Erdoğan Boz). Ankara: Gazi Kitabevi, 247-284.

Şahin, H. (2015). Yabancı kelimelere Türkçe karşllılar bulma sorunu. Türkçenin Çağdaş Sorunları. (ed. Gürer Gülsevin ve Erdoğan Boz). Ankara: Gazi Kitabevi, 285-304.

Tadmor, U. (2009). Loanwords in the world's languages: findings and results. Loanwords in The World Languages A Comporative Handbook. (ed. Martin Haspelmath ve Uri Tadmor). Berlin: Deutsche Nationalbibliothek. 55-75.

TDK, (2011). Büyük Türkçe sözlük. Ankara: TDK Yayınları.

Tekin, S. (2001). Yabancı kelimelerin Türkçeye giriş yolları ve oruç kelimesinin hikâyesi. İştikakçının köşesi Türk dilinde kelimelerin ve eklerin hayat üzerine denemeler, 33-42. İstanbul: Simurg.

Tekten, T. (2009). Türk dilindeki yabancı kelimelerin Türkçe öğretimine etkileri. 1st International Symposium on Sustainable Development, 9-10 June 2009, Sarajevo, Bosnia and Herzegovina.

Ünver, İ. (1991). Yabancı diller etkisinden kurtarılamayan Türkçemiz. Türk Dili, 1991/I, 77-79.

Vardar, B. (2002). Açıklamalı dilbilim terimleri sözlüğü. İstanbul: Multilingual.

Vendelin, I. ve Peperkamp, S. (2004). Evidence for phonetic adaptation of loanwords: an experimental study. Actes des Journées d'Etudes Linguistiques, 2004, 129-131.

Yıldırım, A. ve Şimşek, H. (2006). Sosyal bilimlerde nitel araştırma yöntemleri. Ankara: Seçkin Yayınevi.

Yllmaz, Y. ve Özkurt, E. (2016). Türkiye'de tv program adlarında Türkçeye uygunluk. RumeliDE Dil ve Edebiyat Araştırmaları Dergisi, 7, 1-19.

Yip, M. (1993). Cantonese loanword phonology and optimality theory. Journal of East Asian Linguistics, 2, 261-291. 